\title{
Stekende insecten rondom de Groote Peel Nulmeting 2016
}

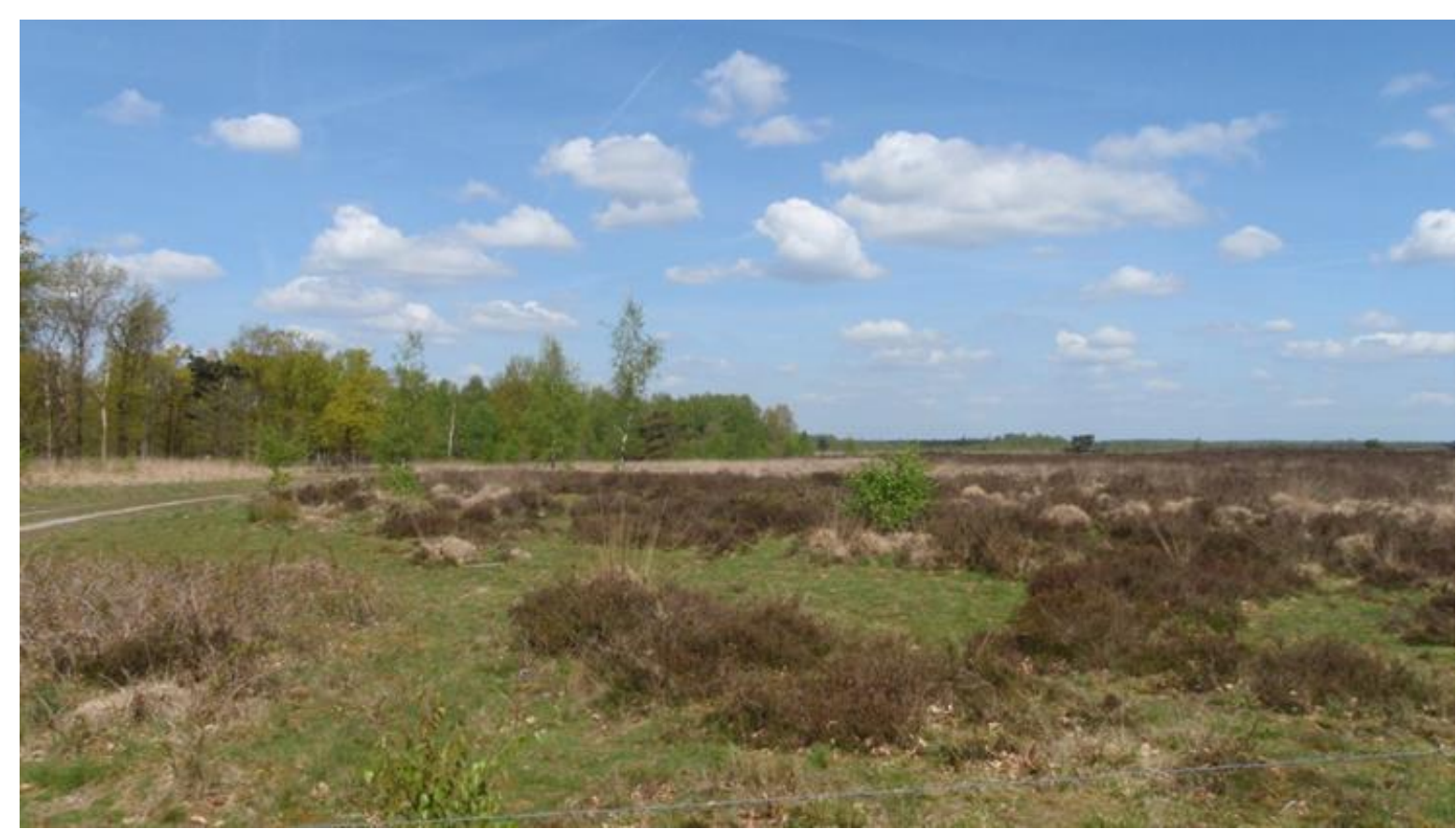

Piet F.M. Verdonschot \& Dorine D. Dekkers

Zoetwaterecosystemen, Wageningen Environmental Research (Alterra)

Februari 2017 


\section{Auteurs}

Piet F.M. Verdonschot, Dorine D. Dekkers

(correspondentie: piet.verdonschot@wur.nl)

\section{Opdrachtgever}

Provincie Noord-Brabant

\section{Projectgroep}

J.P.A. van Leijsen (Provincie Noord-Brabant), Tom Paternotte (Provincie Noord-Brabant)

\section{Wijze van citeren}

Verdonschot, P.F.M. \& Dekkers, T.B.M. (2017) Stekende insecten rondom de Groote Peel. Nulmeting 2016. Notitie Zoetwaterecosystemen, Wageningen Environmental Research, Wageningen. 40 pp.

\section{Trefwoorden}

stekende insecten, steekmug, knut, Mariapeel, deurnsche Peel, Griendtsveen, hoogveenmoeras, overlast

\section{Beeldmateriaal}

Dorine Dekkers

ISBN: 978-94-6343-123-1

DOI: http://dx.doi.org/10.18174/408608

Dit project is uitgevoerd in opdracht van de Provincie Noord-Brabant in het kader van het LIFE+ project Peelvenen LIFE13/Nat/NL/079.

(C) 2017 Zoetwaterecosystemen, Wageningen Environmental Research (Alterra)

- Overname, verveelvoudiging of openbaarmaking van deze uitgave is toegestaan mits met duidelijke bronvermelding.

- Overname, verveelvoudiging of openbaarmaking is niet toegestaan voor commerciële doeleinden en/of geldelijk gewin.

- Overname, verveelvoudiging of openbaarmaking is niet toegestaan voor die gedeelten van deze uitgave waarvan duidelijk is dat de auteursrechten liggen bij derden en/of zijn voorbehouden.

Alterra aanvaardt geen aansprakelijkheid voor eventuele schade voortvloeiend uit het gebruik van de resultaten van dit onderzoek of de toepassing van de adviezen.

\section{Notitie Zoetwaterecosystemen, Wageningen Environmental Research}

Wageningen, februari 2017 


\section{Inhoud}

$1 \quad$ Inleiding en doel $\quad 2$

1.1 Aanleiding 2

1.2 Projectdoelstelling 2

2. Quick-scan risico analyse 3

2.1 Inleiding 3

2.2 Ecologische groepen van steekmuggen en knutten 3

$\begin{array}{ll}2.3 & \text { De Groote Peel }\end{array}$

$\begin{array}{lll}3.1 & \text { Inleiding } & 13\end{array}$

$\begin{array}{lll}3.2 & \text { Werkwijze } & 13\end{array}$

3.2.1 Locaties en bemonsteringsmomenten 13

3.2.2 Bemonsteringstechniek en verwerking 14

4. Resultaten $r$

$\begin{array}{lll}4.1 & \text { Weers- en milieuomstandigheden } & 15\end{array}$

$\begin{array}{lll}4.2 & \text { Resultaten vangsten steekmuggen } & 17\end{array}$

$\begin{array}{lll}4.3 & \text { Resultaten knutten } & 19\end{array}$

5. Discussie en conclusies nulmeting stekende insecten 22

5.1 Steekmuggen $\quad 22$

$\begin{array}{ll}5.2 \text { Knutten } & 27\end{array}$

$\begin{array}{llr}5.3 \text { Conclusies } & 27\end{array}$

$\begin{array}{lr}\text { 6. Referenties } & 28\end{array}$

$\begin{array}{ll}\text { Bijlage 1. } \quad \text { Impressie van de meetlocaties. } & 29\end{array}$

Bijlage 2. Milieukenmerken van de meetlocaties $\quad 33$ 


\section{$1 \quad$ Inleiding en doel}

\subsection{Aanleiding}

De aandacht voor stekende insecten is in de regio sterk toegenomen door de discussie rondom de overlast ervaren door de bewoners van Griendtsveen. Naar aanleiding van 1) het eerste rapport over stekende insecten in en rondom Griendtsveen, 2) de wens van het Waterschap Peel \& Maasvallei om voor de door de provincie aangevraagde vergunning voor het uitvoeren van herstelmaatregelen in het natuurgebied de Groote Peel ook inzicht te geven in de "muggenproblematiek Groote Peel" en 3) vooraf aan de uitvoering van het project LIFE+ Groote Peel een nulsituatie t.a.v. stekende insecten vast te leggen, heeft de provincie Noord-Brabant Wageningen Environmental Research (Alterra) gevraagd om a) het uitvoeren van een risico-analyse op eventueel te verwachten overlast door stekende insecten en $b$ ) het verrichten van een nulmeting stekende insecten.

\subsection{Projectdoelstelling}

Het doel van het project 'Stekende insecten rondom de Groote Peel' is tweeledig:

a) Het verrichten van een Quick-scan risico-analyse van het gebied Groote Peel en met name de mogelijke effecten van de voorgenomen maatregelen in het project LIFE+ op eventuele overlast veroorzaakt door steekmuggen en knutten.

b) Het in 2016 rondom de Groote Peel uitvoeren van een nulmeting om inzicht te krijgen in en het vastleggen van het voorkomen van steekmuggen en knutten rondom de lokaal aanwezige bebouwing en nabij natte randzones. 


\section{Quick-scan risico analyse}

\subsection{Inleiding}

Op 18 februari 2016 is overleg geweest tussen de opdrachtgever en Wageningen Environmental Research (WEnR; voorheen Alterra) om de risico's op stekende insecten rondom de Groote Peel in beeld te krijgen. Aanleiding voor het overleg waren het rapport 'Stekende insecten Griendtsveen Situatie 2015' (Verdonschot et al. 2015) en de notie van de opdrachtgever dat het Waterschap Peel \& Maasvallei voor de door de provincie NBrabant aangevraagde vergunning mogelijk ook inzicht verlangt in de "muggenproblematiek Groote Peel". Dit betekent niet dat er op dit moment een probleem met stekende insecten is in de Groote Peel, maar dat het wel goed is om op voorhand na te gaan waar zich een eventueel probleem zou kunnen voordoen.

Het WEnR-Provincie overleg had een verkennend karakter met als doel een grof beeld te krijgen van de eventuele risico's. WEnR bracht daar haar kennis van stekende insecten in en de provincie legde haar gebiedskennis daarnaast. Op deze wijze kwam op snelle wijze een beeld van mogelijke risico's op stekende insecten rondom de Groote Peel in beeld. Vervolgens heeft WenR op basis van haar kennis een generieke risico-analyse uitgevoerd wat betekent dat op basis van algemene kennis zionder het betrekken van gebiedsspecifieke informatie een generiek beeld van de mogelijke risico's is geschetst.

\subsection{Ecologische groepen van steekmuggen en knutten}

In de discussies rondom de steekmuggen en knutten problematiek in de moerasgebieden spelen de volgende ecologische groepen steekmuggen en knutten een rol:

- Huissteekmuggen ontwikkelen zich in kleine, vaak tijdelijke waterpartijen (vrijwel alle tijdelijke wateren, emmers, badkuipen, regentonnen, blikjes, autobanden, dakgoten en overige antropogene waterpartijen) met sterke wisselingen in milieuomstandigheden. Predatoren ontbreken in deze wateren.

- Moerassteekmuggen ontwikkelen zich meestal in geïsoleerde, ondiepe wateren zoals moerassen, greppels en inundatiezones. De broedplaatsen vertonen een aantal gemeenschappelijke kenmerken: meestal semi-permanent, geïsoleerd van permanente wateren, al dan niet beschaduwd door bomen/hogere begroeiing, veel organisch materiaal op de bodem, waardoor mogelijk lage zuurstofconcentraties optreden en een arme gemeenschap aan overige insecten en ongewervelden (weinig predatoren aanwezig).

- Slootsteekmuggen ontwikkelen zich in permanente wateren met veel plantengroei (vooral drijvende draadalgen en kroossloten of sloten met een ruige oevervegetatie (achterstallig onderhoud)). De wateren hebben een diverse gemeenschap van overige insecten en ongewervelden. Een rijke vegetatie dient als schuilmogelijkheid om een te grote predatiedruk te vermijden.

- Plantenboorsteekmuggen ontwikkelen zich aan (de larve boort in zachte plantendelen en blijft aan de plant aangehecht) dieper groeiende emergente (boven het water uitstekende) water- en oeverplanten. Het betreft vaak kraagvegetaties van lisdodde, riet, liesgras en dergelijke.

- Knutten ontwikkelen zich in allerlei habitats, zoals mest, mierennesten, rottend hout, plantensappen, meren, oeverzones, rivieren, temporaire wateren, boomholten, natte graslanden, laagveenwateren, brakke en zoute wateren en zoute bodems. Overlast voor mensen wordt vooral veroorzaakt door soorten uit 
het geslacht Culicoides. Dit geslacht ontwikkelt zich eveneens in een brede range aan habitats.

De belangrijkste risico-groep in hoogveen ontginningsgebieden zijn de moerassteekmuggen. Samenvattend zijn in een risico-analyse de belangrijkste eisen die moerassteekmuggen stellen aan hun leefomgeving:

- De aanwezigheid van potentiele broedplaatsen. Broedplaatsen zijn ondiepe tijdelijke of droogvallende wateren. De wateren zijn voedselarm en zuur. Moerassteekmuggen leggen hun eitjes in het late voorjaar op de oever van droogvallende plassen. De eieren overwinteren en komen pas na de winter bij stijgende temperaturen uit. Omdat het uitkomen gesynchroniseerd plaats vindt kunnen gelijktijdig in mei-juni hogere aantallen optreden.

- De aanwezigheid van vliegroutes. Moerassteekmuggen verplaatsen zich over vooral door dichte begroeiing, zoals struweel, singels, ruigtes en dicht bos. Boomsingels zijn minder aantrekkelijk. Open terrein (water, kort grasland) is voor moerassteekmuggen vaak een barrière.

\subsection{De Groote Peel}

\section{Landschapstypen}

De potentiële risicolocaties rondom de Groote Peel zouden gebaseerd moeten worden op de eisen van broedplaatsen in het gebied en de vliegroutes. Het bleek echter niet mogelijk om in deze fase de aanwezigheid van potentiële broedplaatsen in beeld te brengen. Tenminste niet meer dan een kwalitatieve inschatting vanuit bij de provincie aanwezige gebiedskennis en een vergelijking met de andere Pelen.

De voor stekende insecten relevante landschapstypen die ook voldoende oppervlak van het gebied innemen zijn opgenomen in Tabel 1.

Tabel 1. Relatie tussen voor steekmuggen relevante vegetatietypen en landschapstypen in de hoogveengebieden zoals de Groote Peel.

\begin{tabular}{|l|l|}
\hline Groep vegetatietypen & Landschapstype \\
\hline Nat Berken-zomereikenbos & nat bos/struweel \\
\hline Elzenbos & $\begin{array}{l}\text { nat bos/struweel } \\
\text { voedselarm }\end{array}$ \\
\hline Natte en vochtige pijpenstroojes vegetatie & $\begin{array}{l}\text { plas-dras/moeras open } \\
\text { voedselarm }\end{array}$ \\
\hline $\begin{array}{l}\text { Natte pitrusruigte } \\
\text { hennegras }\end{array}$ & moeras open voedselrijk \\
\hline Open water & open water \\
\hline Open water met kroos & open water met kroos \\
\hline
\end{tabular}

In het dergelijke hoogveengebieden ontstaan met grote waarschijnlijkheid aanzienlijke dichtheden aan steekmuggen in natte bossen, moerassen en plasdras situaties. De toekomstige landschapstypen in de Groote Peel verschillen waarschijnlijk weinig van de huidige, behalve dat de natte typen in oppervlak uitbreiden t.o.v. de dynamische droog-natte. In het gebied verandert dus wel het oppervlak aan open natte en plas-dras situaties en en moerasvegetaties. 
Alvorens in te gaan op het optreden van steekmugplagen of het inrichten van natte en moerasgebieden ter voorkoming van plagen zijn enkele opmerkingen over de levensstrategie van stekende insecten belangrijk. De meeste stekende insecten hebben een r-strategie. Dit betekent dat stekende insecten snelle groeiers zijn met een korte levensduur, ze investeren veel energie in de reproductie en produceren veel eieren. Het broed wordt niet verzorgd, de sterfte van jonge larven is daarom hoog. Deze levensstrategie is een aanpassing aan het leven in instabiele milieus (bijvoorbeeld pionierstadia, storingssituaties). Van nature zijn steeds ontwikkelingstendensen (successie) aanwezig die de rol van r-strategen doen afnemen ten gunste van de zogenaamde K-strategen (langzame groeiers met een lange levensduur en weinig nakomelingen) door directe wijzigingen in het biologische milieu (zoals het optreden van concurrenten en natuurlijke vijanden, veranderingen in het voedselaanbod) en indirecte wijzigingen in het abiotische milieu (zoals het stabieler worden van fysische en chemische factoren). Om de ontwikkeling van stekende insecten te 'sturen' wordt gebruik gemaakt van deze kennis.

Tabel 2 geeft de samenvatting van de resultaten van een risico-analyse uitgevoerd op de landschapstypen waar in theorie voor de Groote Peel van uit kan worden gegaan. In deze risicoscore is naast de kans op ontwikkelen van stekende insecten het aanwezige oppervlak van het potentieel risicogebied nog niet meegenomen. Ook is het risico afhankelijk van de afstand tot bewoning niet meegewogen. Voor beide onderdelen is gedetailleerde kaartinformatie nodig wat geen onderdeel van het project was. Er moet dus rekening mee worden gehouden dat lokaal het risico groter of kleiner kan zijn afhankelijk van de heersende omstandigheden.

Tabel 2. Risico op stekende insecten

\begin{tabular}{|c|c|c|c|c|c|c|}
\hline $\begin{array}{l}\text { risicosoortgroepen } \\
\text { Landschapstypen }\end{array}$ & 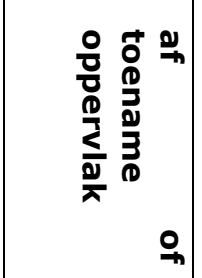 & 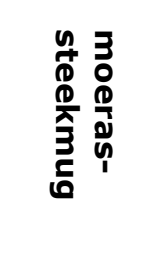 & 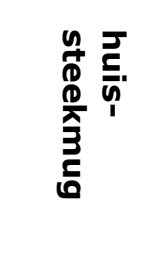 & క气 $\frac{n}{8}$ & 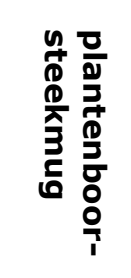 & 졸 \\
\hline Nat bos/struweel & $\begin{array}{c}+ \\
\text { (struweel) } \\
-(\text { nat bos) }\end{array}$ & ++++ & & & & ++++ \\
\hline \multirow{2}{*}{$\begin{array}{l}\text { Plas-dras open matig voedselarm } \\
\text { Moeras open matig voedselarm }\end{array}$} & + & + & +++ & & & $\begin{array}{c}++(+ \\
+)\end{array}$ \\
\hline & + & ++++ & + & & + & ++ \\
\hline $\begin{array}{l}\text { Moeras/oeverzone } \\
\text { voedselrijk }\end{array}$ & - & ++++ & $\begin{array}{c}+++(+ \\
)\end{array}$ & + & $\begin{array}{c}+++( \\
+)\end{array}$ & +++ \\
\hline Open water met kroos & - & & & $\begin{array}{c}++ \\
+\end{array}$ & & \\
\hline Open water & + & & & + & & \\
\hline \multicolumn{7}{|l|}{ Risicoscore $\quad$ Risico-omschrijving } \\
\hline \multicolumn{7}{|c|}{$\begin{array}{l}\text { Geen of zo nu en dan een steek. } \\
\text { Regelmatig een steek of meerdere steken in kortere periode bij buiten zitten. } \\
>1 \text { keer per } 2-3 \text { jaar en langer dan } 2-3 \text { weken niet meer lekker buiten kunnen } \\
\text { zitten. }\end{array}$} \\
\hline $\begin{array}{l}\text { Jaarlijks } 2-3 \text { weken } \\
\text { Jaarlijks meerdere }\end{array}$ & \multicolumn{6}{|c|}{ Jaarlijks 2-3 weken niet meer lekker buiten kunnen zitten. } \\
\hline
\end{tabular}


Inrichtingsmaatregelen en risico

Het doel van de voorgenomen maatregelen in de Groote Peel is het ontwikkelen van actief hoogveen. De uiteindelijk toestand is een voedselarm hoogveen gebied. De belangrijkste maatregelen betreffen, zoals we in deze verkenning aannemen, het dempen, verondiepen of afdammen van watergangen, het eventueel aanleggen van kades / het (verder) compartimenteren van het gebied en het (plaatselijk) verhogen van het waterpeil.

Bij maatregelen in hoogveengebieden wordt altijd gestreefd naar een constanter peil. Echter vaak treden in randzones of zones waar zand in de ondergrond zit of waar lekken in de ondoorlatende ondergrand zijn, minder stabiele situaties op. In dergellijke gebieden ontstaan tijdelijke plas-dras situaties die een hoog risico $(++++$ of hoger) op overlast door moerassteekmuggen met zich meebrengen. Omdat eieren van deze moerassteekmuggen meerdere jaren in de oeverzones van plassen bewaard kunnen blijven kan de muggenpopulatie in het ergste scenario in een uitzondelijk nat jaar exploderen. Dit is de mechanisme waarmee de muggenplaag bij Engbertsdijksvenen in 1987 is ontwikkeld. Mogelijke maatregelen: Constant peil handhaven, droger houden en voldoende buffer tussen het risicogebied en bewoning aanleggen.

De risico's in de mogelijk belangrijkste landschapstypen kunnen als volgt worden geduid:

- Permanent open water (bv. sloten en greppels, plassen, venachtige poelen en weilandpoelen)

Risico: geen (0) tot zeer laag (Slootsteekmuggen + ). Het open water is permanent, er leven rovers (zoals talrijk in de Groote Peel de hondsvis, of libellenlarven en roofkevers). Mogelijke maatregelen: Geen of bij slibophoping en dichtgroeien van sloten voorkomen door regelmatig schonen (1-4x jaar).

- Permanent open water met kroos (vaak sloten met invloed vanuit agrarisch gebied)

Risico: aanwezig (Slootsteekmuggen +++ ). Het open water is permanent, maar door de krooslaag heeft de sloot een slechte zuurstofhuishouding en leven er maar weinig rovers. Mogelijke maatregelen: Voorkomen van te hoge voedingsstoffengehalte zodat geen kroosontwikkeling optreedt of beschaduwing. Door regelmatig verwijderen van voedselrijk bodemslib (baggeren) kan de kroosontwikkeling worden beperkt.

- Moeras en oeverzone open voedselrijk

Risico: hoog (steekmuggen en knutten $(++++)$ ). Hoog risico omdat oeverzones met flauwe talus en moerassen met tijdelijk open water en modderige zones rondom de vegetatie ideale brioedplaatsen zijn voor verschillende groepen steekmuggen. Door de hogere voedselrijkdom is er ook voldoende voedsel beschikbaar. Pijpenstrootjesvegetaties en zeggevelden e.d. hebben een hoog risico omdat het gebied lange tijd nat tot onder water staat. De ondiepe wateren zijn broedplaatsen voor steekmuggen en de ondiepe bodem rondom rietstengels zijn broedplekken voor knuttten. Het risico wordt groter indien het terrein de volgende kenmerken gaat dragen: bultenslenken, verruigd, beweid, veenbodem en voedselrijker (ex-landbouwgrond).

Maatregelen: Voor oeverzones geldt het inrichten van een regelmatig aflopend en steiler talud en het regelmatig schonen ((1)2-4 x jaar). Het risico wordt nog groter indien de oeverzone met lage helofyten of de slootoever de volgende kenmerken gaat dragen: bulten-slenken, verruigd, extensief betreden door vee, veenbodem en voedselrijker (ex- 
landbouwgrond). In de verbrede sloten kan een constant peil en goede waterkwaliteit bijdragen aan verlagen van het risico.

Voorkom bij moerassen dat jaarlijks hetzelfde inundatieregime optreedt. Het iets verdrogen of iets verder vernatten met greppels of schuin aflopend terrein. Het regelmatig plegen van onderhoud: maaien en vlak houden. Niet of alleen licht beweiden. De periode van zomerinundatie kort houden en/of niet herhalend laten optreden, zeker niet in afwisseling met droogval.

\section{Voorbeeld Compartiment 30 (med. provincie)}

Compartiment 30 direct ten noorden van Ospeldijk (Figuur 1) is nu een Kruiden en Faunarijk grasland dat door Staatsbosbeheer wordt beheerd met runderen. Grote delen zijn vrij nat en begroeid met pitrus. Water kan vrij gemakkelijk afstromen naar het slotenstelsel.

In de nieuwe situatie wordt er een kade aangelegd rondom dit perceel en wordt een stuwpeil ingesteld van 27,90 m+NAP. Dit compartiment is een ondersteunend compartiment. Bij een stuwpeil van 27,90 m+NAP komen de lage gebiedsdelen (groene en blauwe delen in Figuur 1) onder water. Wanneer deze plekken in het late voorjaar nog onder water staan en daarna droog vallen zijn dit in potentie broedlocaties voor moerassteekmuggen.

In de praktijk zal dit compartiment vooral in najaar en winter plasdras staan, in het voorjaar droog vallen en in de zomer droog staan. Of er overlast van muggen ontstaat, hangt er dus van af of dit compartiment in het late voorjaar nog ondiep open water bevat. Daarin kan de beheerder sturen.

- De beheerder kan in mei water versneld afvoeren door het stuwtje in kade 1 open te zetten.

- De beheerder kan in een nat voorjaar water langer (tot ver in de zomer) vasthouden door het stuwtje in kade 1 omhoog te zetten.

- De beheerder kan zorgen voor een korte open vegetatie. Ontwikkeling van struweel en ruigte zou vermeden moeten worden.

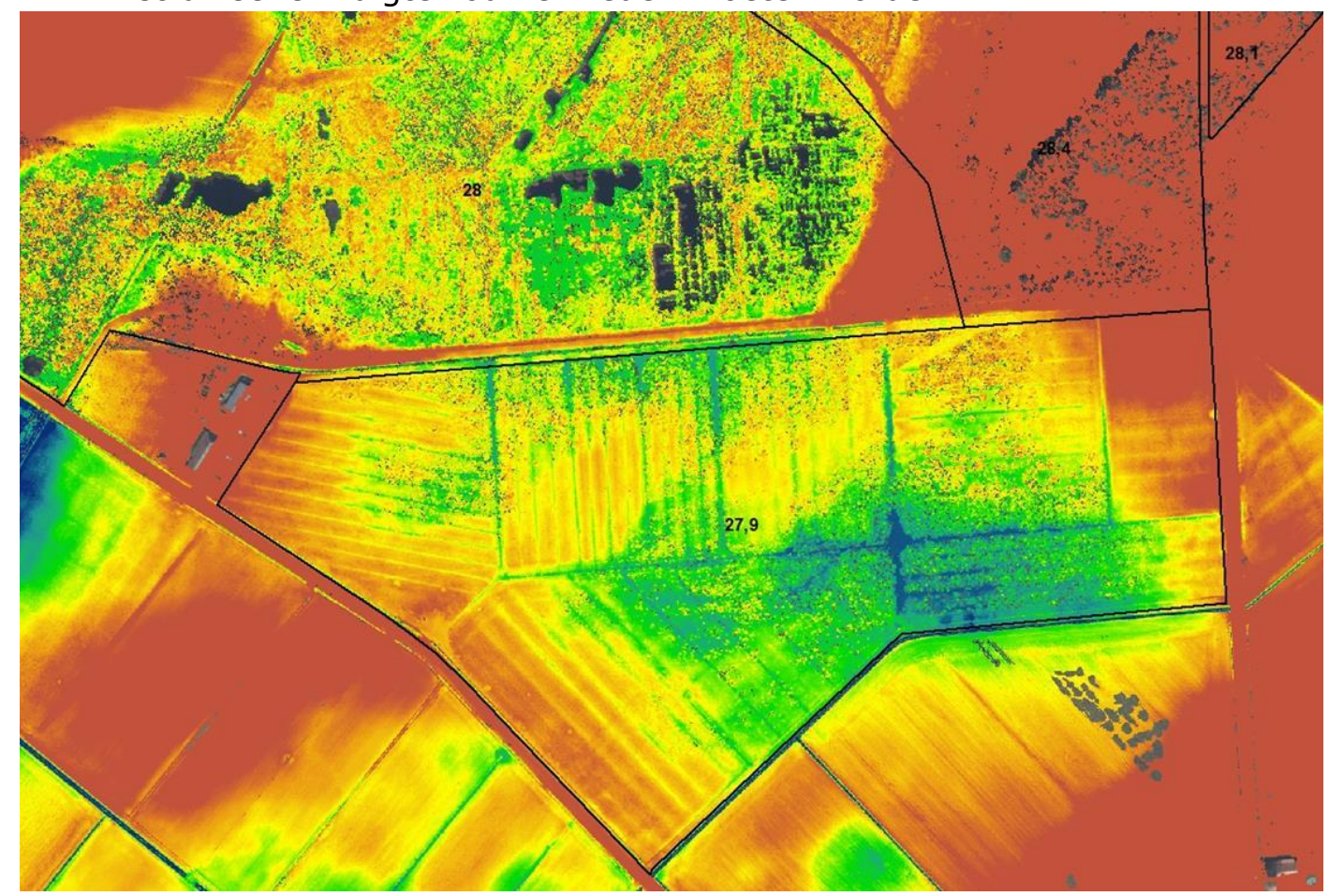


Figuur 1. Hoogtekaart van compartiment 30 (zie ook Figuur 2). Van blauw laag naar rood hoog.

- Moeras open matig voedselarm

Risico: hoog voor moerassteekmuggen $(++++)$ en aanwezig voor knutten $(++)$. Hoog risico op moerassteekmuggen omdat deze voorjaarssoorten aangepast zijn aan moeras-, pijpenstrootjes- en zeggenvegetaties e.d. Degelijke gebieden hebben een redelijk voorspelbare waterstand die in het voorjaar hoog is. De steekmuggen komen daardoor synchroon uit en treden in die maanden dan ook talrijk op. In de zomer zijn ze verdwenen. De ondiepe bodem rondom stengels biedt broedplekken aan knuttten. Het risico wordt groter indien het terrein de volgende kenmerken gaat dragen: bultenslenken, verruigd, beweid, veenbodem en voedselrijker (ex-landbouwgrond) met vooral meer wisselingen in de waterstand.

Maatregelen: Dergelijke gebieden met moerassteekmuggen zijn onderdeel van het natuurlijke systeem. Belangrijk is de voedselrijkdom laag te houden en de waterstand niet onregelmatig fluctuerend (peilbeheer).

- Plas-dras open matig voedselarm

Risico: Steekmuggen laag $(+)$, behalve indien plas-dras situaties in de zomer fluctueren (huissteekmuggen aanwezig $(+++)$. Knutten aanwezig $(++)$ of hoog indien het water in de zomer tot juist onder maaiveld blijft. Het risico wordt groter indien het terrein de volgende kenmerken gaat dragen: bulten-slenken, verruigd, beweid, veenbodem en voedselrijker (ex-landbouwgrond).

Maatregelen: Voorkomen dat jaarlijks hetzelfde inundatieregime optreedt. Voorkom voedselverrijking. Het voorkomen dat water in de zomer $>10$ dagen op het maaiveld achterblijft. Het regelmatig plegen van onderhoud: maaien en vlak houden. Niet of alleen licht beweiden. De periode van zomerinundatie kort houden en/of niet herhalend laten optreden, zeker niet in afwisseling met droogval. Het grondwater onder maaiveld in de zomer iets laten wegzakken.

- Nat bos/struweel

Risico: hoog $(++++)$.

Maatregelen: Zorg dragen dat geen tijdelijk water tot in mei achterblijft of constant peil handhaven of peil tot maaiveld zodat geen open water aanwezig is of meer open water creeeren en onderling met permanent water verbinden. Daarnaast kan bos voor volwassen muggen als verbinding functioneren; dan boscorridor onderbreken. Tegelijk kan bos als refugium werken en daarom pleksgewijs bos aanbrengen.

- Bos (droog)

Risico: geen (0)

Maatregelen: Geen. Bos werkt wel als schuilplaats voor volwassen stekende insecten.

Aanlegfase, rabnd- of bufferzones en eindtoestand

Indien belangrijke gebiedsdelen in de Groote Peel voedselarm worden waarbij veenmos ontwikkelt, trilveen ontstaat en de waterstand stabiel is, dan nemen de risico's op stekende insekten sterk af (risico laag $(+)$ tot 0 ). Het in de Groote Peel nagestreefde eindbeeld draagt deze kenmerken. Om die reden is het steeds van belang de aandacht vooral te richten op de overgangs- en buffergebieden tussen de natuur en agrarische gebieden. Hier zullen zeker na de aanlegfase meer schommelingen in de waterstand optreden en zal de voedselrijkdom hoger zijn. Maatregelen om verdere toename in 
stekende insekten te voorkomen moeten daarom vooral gericht worden op deze zone, de waterstand en de voedselrijkdom.

In de hydrologisch dynamisch (moeilijk stuurbare bijvoorbeeld door aanwezigheid van doorlatende ondergrond), overgangs- en buffergebieden betreft het de maatregelen:

- Instellen en handhaven van een zo constant mogelijk water en grondwaterpeil of zorgen dat oppervlaktewater slechts kort in het voorjaar boven maaiveld blijft staan.

- Een open zone die als barriere werkt tussen bewoning en natuurgebied de Groote Peel.

- Pleksgewijs laten staan van bossages binnen het natuurgebied die als opvangbosjes werken voor stekende insekten.

- Voorkomen van voedselverrijking.

- Voorkomen dat aan- en afvoersloten verrijken en verlanden (regelmatig schonen). Tijdens en na een inrichtings- of aanlegfase (tot 5 jaar na ingreep) ontstaan vaak veel nieuwe tijdelijke wateren die zich vormen na afgraven, verwijderen van bomen of de aanleg laagtes/slenken. Hier gedijen steekmuggen uitstekend. Dergelijke gebieden hebben een risico op veel stilstaand water en nat-droog situaties waarin rovers ontbreken nog en dat geeft kansen op broedplaatsen voor steekmuggen. Bij een natte veenbodem kunnen knutten en dazen ontwikkelen. $\mathrm{Na}$ aanleg is het vinger-aan-de-pols-houden door regelmatig monitoren (hiertoe worden enkele monitoringslokaties gekozen aan de zijde van de bewoning en in de rand van het gebied en deze plekken worden maandelijks tussen april en september gemeten gedurende 24 uur). Het advies is sowieso bij voorkeur na de zomer in te richten of aan te leggen.

\section{Afstand tussen broedgebieden en bewoning}

Een ruime afstand tussen mogelijke broedgebieden van steekmuggen en knutten en bewoning (de plaats waar de volwassen steekmuggen naar toe vliegen) kan effectief werken tegen bepaalde soorten steekmuggen en knutten en overlast beperken. Broedgebieden zijn de plaatsen waar steekmuggen/knutten hun eitjes afzetten (op natte grond of op water) en waar de larven zich ontwikkelen (in de waterkolom) om via popstadium (in de waterkolom levend) te komen tot volwassen steekmuggen/knutten (die uit het water uitvliegen). Wanneer het tussenliggend gebied steekmug en knut onvriendelijk wordt ingericht gaat het tussenliggende gebied als barrière werken.

Steekmuggen zijn in 4 groepen vliegers zijn te verdelen: sterke, goede, matige en zwakke vliegers. Barrières verminderen het aantal stekende insecten dat woningen bereikt altijd. De effectiviteit van barrières hangt samen met drie verschillende aspecten: Van veel Nederlandse soorten stekende insekten is de vliegcapaciteit niet bekend. Van sommige knutten is bekend dat het zeer goede vliegers zijn. Er is een mismatch tussen ecologische groepen van huissteekmuggen, slootsteekmuggen, moerassteekmuggen en plantenboorsteekmuggen en de vier vlieggroepen. Met andere woorden: binnen iedere ecologische groep van steekmuggen kunnen zowel zwakke als sterke vliegers zitten. Dit laatste resultaat betekent dat het van de lokale omstandigheden afhangt of een barrière zin heeft, omdat het van deze omstandigheden afhangt welke soort zich ontwikkelt. Wanneer bekend is welke soort of soorten zich ontwikkelen of kunnen ontwikkelen en welke vliegcapaciteit die hebben, kan pas aangegeven worden of een barrière meer of minder effectief zal zijn. Bosmoerassteekmuggen bijvoorbeeld zijn zwakke vliegers en daar kan een smalle barrière al veel effect oogsten.

Afstand en inrichting van van randzones 
De overlast veroorzaakt door zwakke en matige vliegers (steekmuggen en knutten kunnen gegroepeerd worden in groepen van zwakke tot zeer sterke vliegers wat afhankelijk is van de soort) kan met barrières die op een juiste manier zijn ingericht worden beperkt. Een barrière van $50-70 \mathrm{~m}$ geeft een $90 \%$ vermindering in aantallen zwakke vliegers terwijl dit bij matige vliegers met 140- $200 \mathrm{~m}$ wordt bereikt. Voor de goede en sterke vliegers zijn veel bredere barrières nodig om een $90 \%$ vermindering te bereiken. Verder zijn de afstandsmaten indicatief omdat ze mede afhangen van de prooidichtheid, de kwaliteit van de barrière, de dichtheid van de populatie enz. Dus als bijvoorbeeld als het broedgebied verre van optimaal is en er dus maar heel lage aantallen steekmuggen optreden is een $90 \%$ reductie niet nodig om toch geen overlast te krijgen. De inrichting van een barrière is gericht op het bereiken van een lage luchtvochtigheid (te bereiken met zeer korte vegetatie of open water), vrijheid voor windwerking (wind beperkt de vliegmogelijkheden sterk) en ontbreken van corridors in de vorm van linten van bosschages of ruigten. Een extra versterking van een barrière is het aanleggen van bosschages aan de binnenzijde van het broedgebied om volwassen steekmuggen en knutten juist het gebied in te trekken i.p.v. het gebied uit, richting woningen, te laten vliegen. Deze zogenoemde muggenbosjes versterken de barrièrewerking.

De potentiële vliegroutes van moerassteekmuggen vanuit de Groote Peel naar bebouwing bestaan uit verbindingen met dichte (struweel) begroeiing tussen natte delen in de Groote Peel en bebouwing in de omgeving (Figuur 2; opgesteld door de provincie).

- Rondom de Groote Peel zijn dat vooral routes naar individuele boerderijen en huizen (door de provincie in Figuur 2 in rood aangegeven). Met name aan de Kokmeeuwenweg staan huizen direct tegenover bos (met deels een dichte ondergroei). Verder grenst de boerderij van Madou aan bosgebied van de Groote Peel. Ook aan de Tureluurweg staat een boerderij direct grenzend aan bosgebied.

- Aan de Limburgse kant grenzen 2 woonlocaties direct aan bosgebied van de Groote Peel. De ene locatie aan de Moostdijk, direct ten westen van het bezoekerscentrum, de andere locatie aan de Oude dijk.

- $\quad \mathrm{Er}$ is een potentiële verbindingszone voor moerassteekmuggen naar Neerkant (door de provincie in Figuur 1 in groen aangegegeven). De afstand van de moerassige delen in CO24 tot de rand van Neerkant (Reigerbekweg) is ca. 800 meter en er komen veel steekmuggen voor in het moerasbos van $\mathrm{CO} 24$ (med. provincie).

De werkelijke rol van deze mogelijke vliegroutes hangt af van de soort die hier gebruik van zou kunnen maken en de hierboven genoemde criteria. 


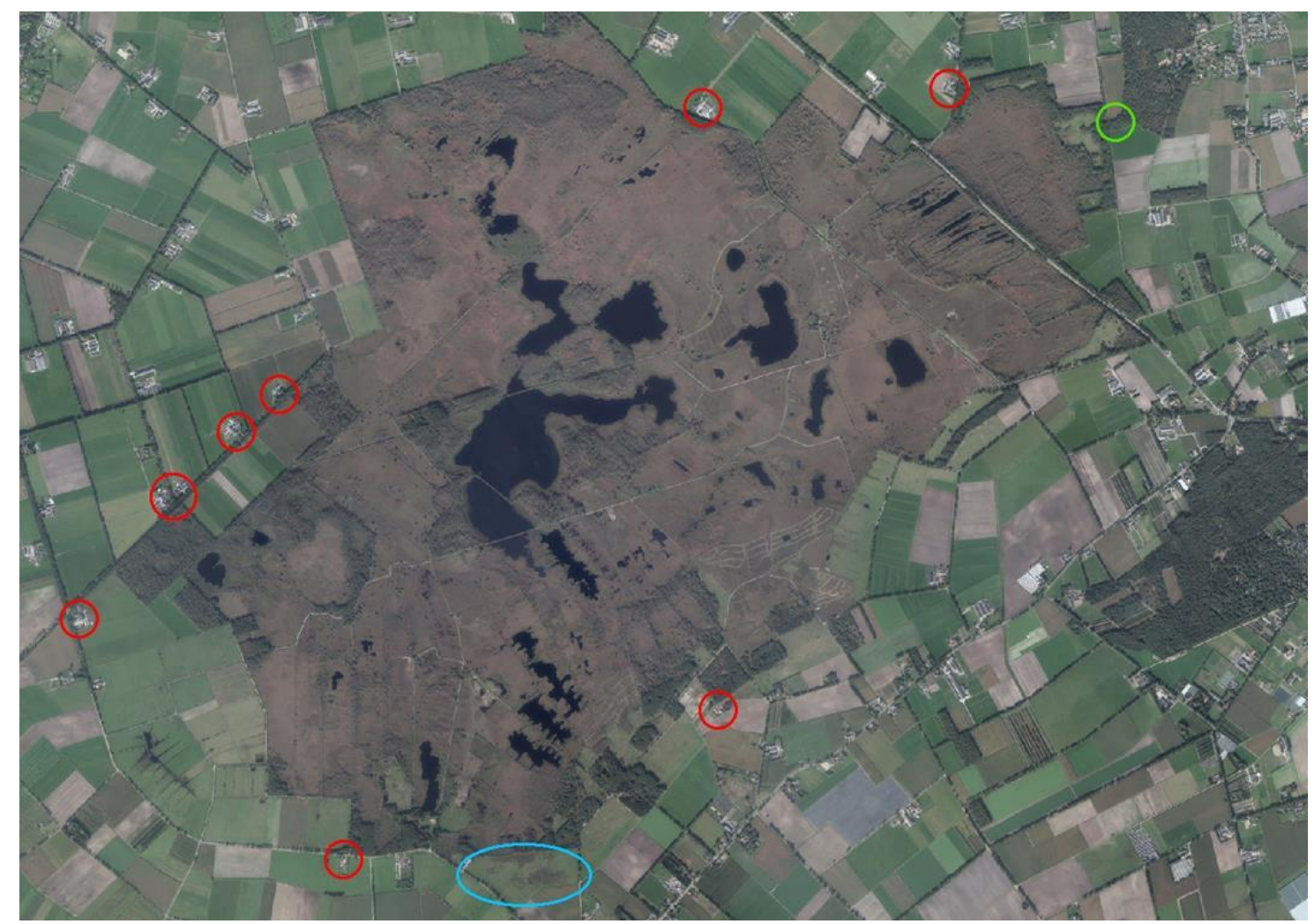

Figuur 1. Ligging van potentiele vliegroutes vanuit de Groote Peel naar omliggende bebouwing. Rode ellips: vliegroute naar individuele boerderijen en huizen; Groene ellips: potentiële verbindingszone; Blauwe ellips: compartiment 30 (zie Figuur 1).

Aard, het oppervlak en de kwaliteit van het broedgebied

De habitatkwaliteit en het oppervlak van broedplaatsen is van groot belang bij de inschatting van potentiele overlast. Dit is een belangrijk onderdeel van de risico inschatting. Het ligt voor de hand dat hoe groter de oppervlakken aan potentieel broedgebied, hoe groter de kans op overlast zal zijn omdat er dan meer larven volwassen worden. Als dan ook de habitatkwaliteit van de specifieke broedplek optimaal is dan kunnen zich nog hogere aantallen stekende insekten ontwikkelen. Vaak zijn wisselend droog-natte oftewel dynamische landschapstypen de belangrijkste bon voor overlast van steekmuggen, omdat daar kwaliteit en kwantiteit van broedgebied het hoogst zijn. Dynamische omstandigheden treden bijvoorbeeld op na afgraven of plaggen. Voor knutten is het moeilijker te definiëren wanneer de kwaliteit van het broedgebied het hoogst is maar het hangt samen met grondwater aan maaiveld en voedselrijkdom.

Een ander voorbeeld bij oppervlak zijn de broedplaatsen van slootsteekmuggen, die vooral te vinden zijn in permanente oppervlaktewateren met veel plantengroei of flabontwikkeling. Gezien de ruimtelijk spreiding en het beperkte oppervlakte van sloten in hoogveengebieden zal het voorkomen van deze steekmuggen niet tot overlast (zie kader) leiden.

\section{Wat is overlast?}

Ieder mens ervaart overlast verschillend. Bij de risicoanalyse op steekmuggen en knutten is het begrip overlast wel van groot belang. Een referentienorm voor overlast is voor Nederland niet opgesteld. Belangrijk is daarom de bestaande situatie zo kwantitatief mogelijk vast te stellen om deze in de toekomst met de nieuwe situatie te kunnen vergelijken. 
Het aanleggen van barrières helpt altijd maar dat de effectiviteit is niet alleen afhankelijk is van (1) de soort met een bepaalde vliegcapaciteit (4 vlieggroepen), maar ook van (2) de inrichting van de buffer ('Hoe onneembaar is de barrière voor de steekmug of knut?'), (3) de aard (in relatie tot de ecologische groepen steekmuggen en knutten), het oppervlak en kwaliteit van het broedgebied en (4) de ruimtelijke positionering t.o.v. bosschages en woningen. Dit betekent dat bovengenoemde 4 aspecten in relatie tot de weersomstandigheden, omdat die uiteindelijk de dynamiek van het water sturen, in de discussies rondom buffers en barrières meegenomen moeten worden. Deze complexiteit vraagt om een lokale benadering.

\section{Aanbevelingen t.a.v. de generieke risico-analyse}

Uit deze generieke risico-analyse volgen de volgende adviezen:

- Het geven van voorlichting aan de omwonenden.

- Het gebruiken van het advies bij inrichting en toekomstig beheer. Het belangrijkste advies is ondanks dat in het natuurgebied het leefgebied voor muggen zelfs zou kunnen toenemen (het streven is gelijk houden of verkleinen) er een effectieve barriere kan worden opgeworpen tussen het natuurgebied en de bewoning. Als dat gebeurd dan is het risico op overlast door muggen belangrijk verlaagd.

- Het monitoren (vóór aanleg en tijdens de eerste ontwikkelingsfase van het gebied) om tijdig aanvullende maatregelen te kunnen nemen door;

○ nulsituatie bij bewoning vastleggen (referentie).

Het vastleggen van de nulsituatie / referentie is nuttig wanneer na de inrichting een discussie ontstaat over wel of niet sprake van de vergroting van het overlast. Het monitoren na aanleg helpt bij het vinger-aan-de-pols houden van de situatie zodat de overlast tijdig kan worden voorkomen.

De mogelijke maatregelen zijn nogmaals samengevat in Tabel 3.

Tabel 3. Samenvatting mogelijke maatregelen op basis van de generieke risico-analyse.

\begin{tabular}{|c|c|c|}
\hline Landschapstypen & Maatregel & Aandacht voor \\
\hline Nat bos/struweel & constant peil & voorkomen corridors \\
\hline \multirow{2}{*}{$\begin{array}{l}\text { Plas-dras open matig voedselarm } \\
\text { Moeras open matig voedselarm }\end{array}$} & begreppelen & \multirow{2}{*}{$\begin{array}{c}\text { voorkomen } \\
\text { voedselverrijking, geen } \\
\text { corridors }\end{array}$} \\
\hline & constant peil & \\
\hline $\begin{array}{l}\text { Moeras/oeverzone } \\
\text { voedselrijk }\end{array}$ & constant peil, verarmen & voorkomen corridors \\
\hline Vochtig matig voedselrijk grasland & vlak aflopend (geen reliëf) & $\begin{array}{l}\text { Voorkomen inundatie en } \\
\text { beweiden, begreppelen }\end{array}$ \\
\hline Nat voedselrijk grasland & $\begin{array}{l}\text { peilverhoging najaar } \\
\text { vlak aflopend (geen reliëf) } \\
\text { (geen zomerinundatie) }\end{array}$ & beweiden, maaien \\
\hline Overstroomd voedselrijk grasland & vlak aflopend (geen reliëf) & beweiden, maaien \\
\hline Open water met kroos & schonen, verarmen & regelmatig schonen \\
\hline Open water & & regelmatig schonen \\
\hline
\end{tabular}




\section{Nulsituatie Stekende insecten Groote Peel}

\subsection{Inleiding}

Om de nulsituatie t.a.v. stekenede insecten in 2016 vast te leggen is een monitoringsonderzoek naar de aanwezigheid en dichtheid van volwassen steekmuggen en knutten rondom de Groote Peel uitgevoerd. De werkwijze en resultaten worden hierna besproken.

\subsection{Werkwijze}

\subsubsection{Locaties en bemonsteringsmomenten}

De locaties zijn aan de hand van de resultaten uit de quick-scan risicoanalyse bepaald. Voor de volwassen steekmuggen en knutten zijn, in overleg met de opdrachtgever, uiteindelijk 14 monitoringslocaties verdeeld rondom de Groote Peel (Figuur 3, Tabel 4, Bijlage 1) geselecteerd.

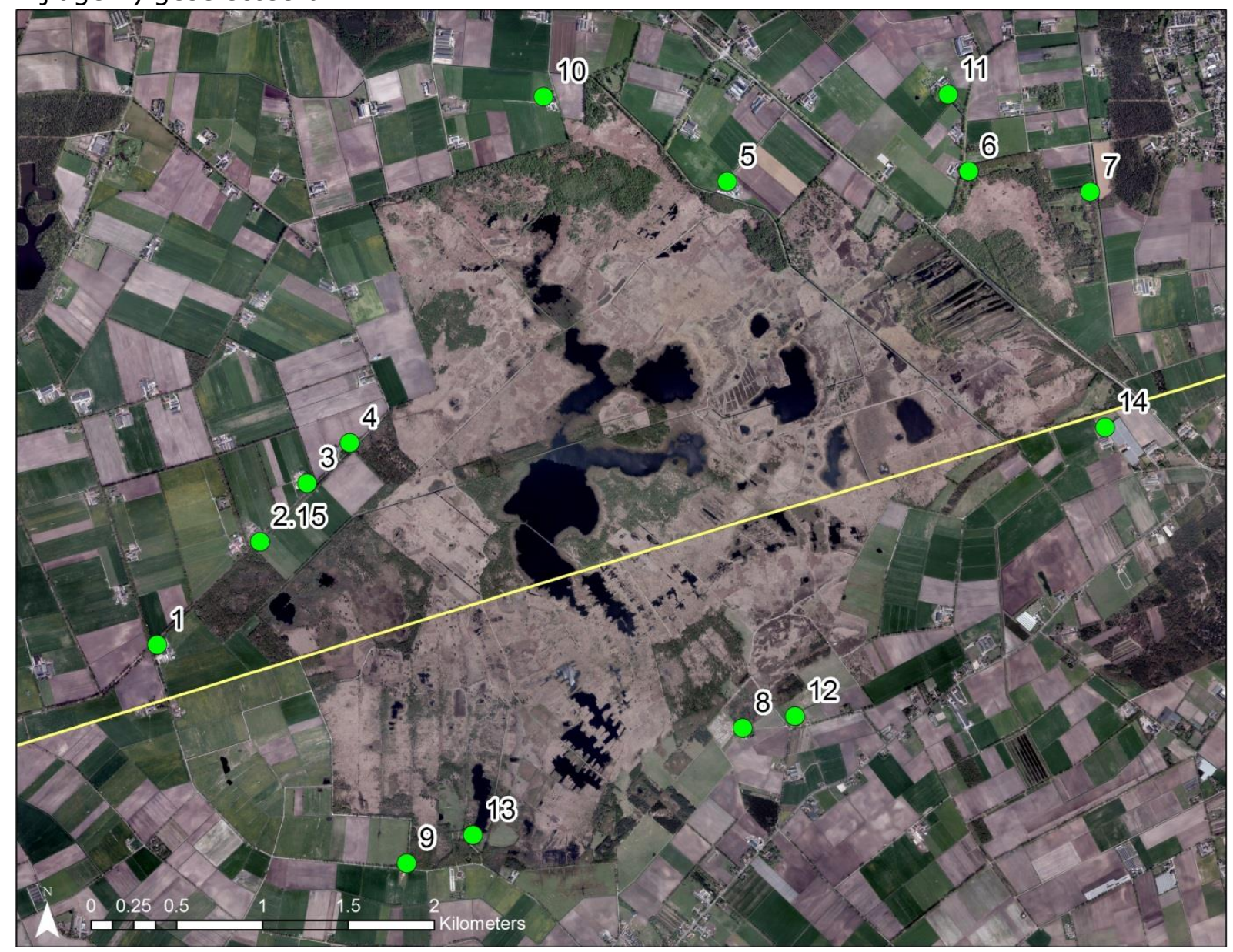

Figuur 3. Ligging van de monitoringslocaties rondom de Groote Peel. 
Tabel 4. Overzicht van de monitoringslocaties met $x$ - en $y$-coördinaten rondom de Groote Peel.

\begin{tabular}{|l|l|l|l|l|}
\hline \multicolumn{2}{|l|}{ Locatie } & \multicolumn{2}{l|}{ Coördinaten } & \multirow{2}{*}{ Onmschrijving } \\
\cline { 1 - 3 } $\mathbf{n r}$ & adres & $\mathbf{X}$ & $\mathbf{Y}$ & $\begin{array}{l}\text { Koorzijde woning, bij haag rondom tuin, bij greppeltje } \\
\text { en varens }\end{array}$ \\
\hline 2.15 & $\begin{array}{l}\text { Kokmeeuwenweg } \\
26\end{array}$ & 182.720 & 372.749 & overzijde van erf, in strook met bomen en struiken \\
\hline 3 & $\begin{array}{l}\text { Kokmeeuwenweg } \\
24\end{array}$ & 182.499 & 373.077 & voorzijde woning, naast haag in tuin, bij gouden regen \\
\hline 4 & $\begin{array}{l}\text { Kokmeeuwenweg } \\
22\end{array}$ & 183.237 & 373.296 & voorzijde woning, in border onder 'open' struiken \\
\hline 5 & Kluutweg 7 & 185.439 & 374.843 & $\begin{array}{l}\text { voorzijde woning, in border, onder struikgewas bij } \\
\text { voedersilo }\end{array}$ \\
\hline 6 & Tureluurweg 2 & 186.819 & 374.899 & $\begin{array}{l}\text { rechts naast woning in bosrand, achter rhododendron } \\
\text { struiken }\end{array}$ \\
\hline 7 & Tureluurweg & 187.546 & 374.783 & in bosrand tussen Reigersbekweg en Tureluurweg \\
\hline 8 & Oude dijk 7 & 185.530 & 371.666 & achter huis in bosrand, bij beukenhaag \\
\hline 9 & Moostdijk 19 & 183.574 & 370.878 & overzijde weg bij huis, in bosrand \\
\hline 10 & Vossenbaan 4 & 184.369 & 375.339 & onder bomen bij mestsilo \\
\hline 11 & Tureluurweg 7 & 186.715 & 375.349 & begin van erf, in haag met struiken \\
\hline 12 & Oude Dijk 11 & 185.833 & 371.735 & achter huis bij ruiterpad in bosje SBB \\
\hline 13 & Meerbaan & 183.960 & 371.043 & in bosrand aan Meerbaan \\
\hline 14 & Berg 6 & 187.639 & 373.415 & $\begin{array}{l}\text { einde van erf, bij kuil plaats, in strook met bomen en } \\
\text { struiken rondom greppel }\end{array}$ \\
\hline
\end{tabular}

Volwassen steekmuggen en knutten zijn verzameld in de periode begin mei tot en met eind september 2016. Er zijn in totaal zes meetrondes uitgevoerd op respectievelijk:

- 3 en 4 mei

- 9 en 10 juni

- 29 en 30 juni

- 25 en 26 juli

- 30 en 31 augustus

- 26 en 27 september

\subsubsection{Bemonsteringstechniek en verwerking}

Op ieder monitoringspunt is een speciale val voor steekmuggen en knutten aan het einde van de middag geplaatst en opengezet. De vallen zijn operationeel vanaf het moment van open zetten tot de volgende ochtend, waarop ze zijn gesloten en geleegd. Deze bemonsteringstechniek is een voor Europa gestandaardiseerde methode.

Tellingen en determinaties van de gevangen steekmuggen en knutten zijn kort na iedere bemonstering uitgevoerd. 


\section{Resultaten}

\subsection{Weers- en milieuomstandigheden}

Het jaar 2016 begon met uitzonderlijk zachte wintermaanden januari en februari met slechts een korte vorstperiode (Figuur 4). Vervolgens was de maand maart gemiddeld te koud en april gemiddeld te warm t.o.v. het langjarig gemiddelde (de normaal). De maanden mei tot en met juli en september waren over het algemeen warmer dan normaal terwijl augustus gemiddeld tot iets koeler was (Figuur 4).

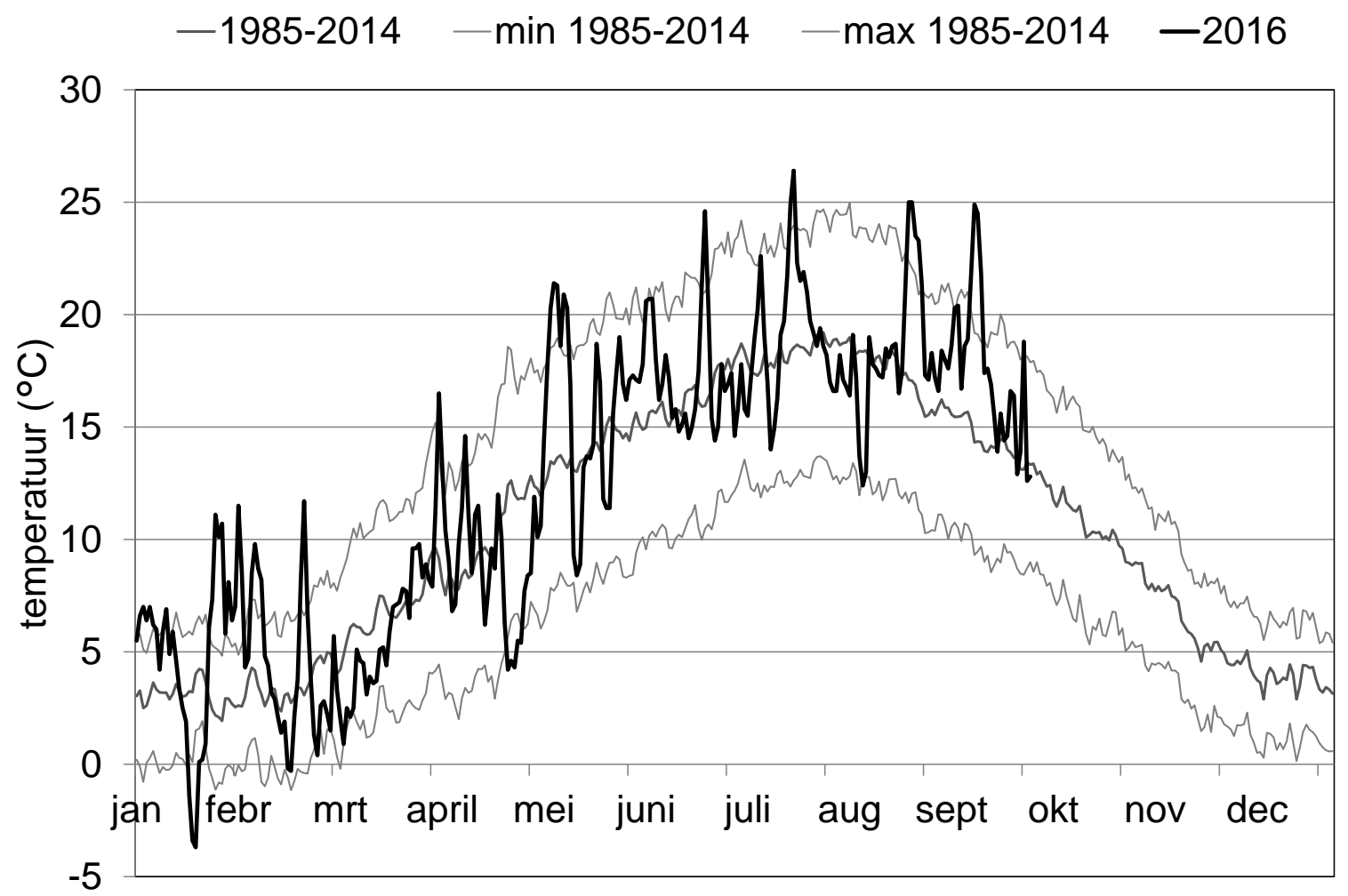

Figuur 4. Etmaalgemiddelde van de temperatuur op station Eindhoven in 2016 en etmaalgemiddelde, maximum en minimum over de periode 1985-2014 (Bron: KNMI: http://www.knmi.nl/nederland-nu/klimatologie/daggegevens).

De maanden januari en februari waren relatief nat terwijl de drie daarop volgende maanden relatief droog waren (Figuur 3). De maand jjuni was extreem nat. Tussen de monitoringsmomenten van begin en eind juni viel in totaal in drie weken bijna $190 \mathrm{~mm}$ regen. Juli tot en met september waren weer uitzonderlijk droge maanden (Figuur 5). 


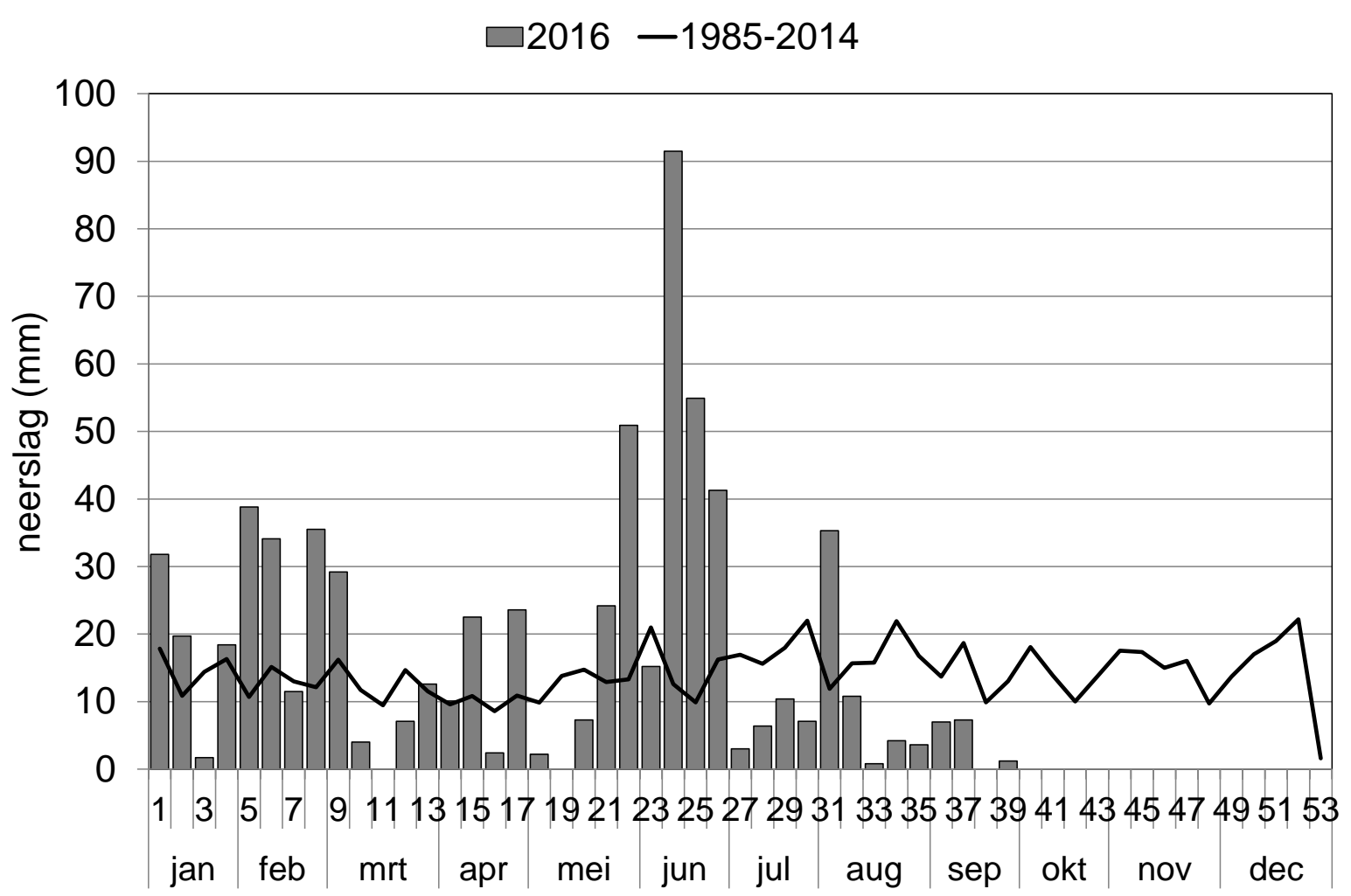

Figuur 5. Weeksom van de neerslag op station Eindhoven in 2016 en weeksom van daggemiddelden over de periode 1985-2014

(Bron: KNMI: http://www.knmi.nl/nederland-nu/klimatologie/daggegevens).

De metingen aan stekende insecten zijn allemaal onder normale weersomstandigheden uitgevoerd (Tabel 5 en Bijlage 2). Dat betekent dat temperatuur, luchtvochtigheid, neerslag en wind geen tot relatief weinig invloed hebben gehad op de vangstaantallen. Uitzondering zou de combinatie neerslag en wind kunnen zijn geweest tijdens de eind juni meting.

Tabel 5. Dagwaarden van meteogegevens op station Eindhoven tijdens de meetdagen (Bron: KNMI: http://www.knmi.nl/nederland-nu/klimatologie/daggegevens).

\begin{tabular}{|c|c|c|c|c|c|c|c|c|c|c|c|c|c|}
\hline \multirow{3}{*}{ Datum } & \multicolumn{3}{|c|}{ Temperatuur } & \multicolumn{3}{|c|}{ Luchtvochtigheid } & \multicolumn{2}{|c|}{ Neerslag } & \multicolumn{2}{|l|}{ Wind } & \multirow{2}{*}{$\begin{array}{l}\text { Bewol- } \\
\text { king }\end{array}$} & \multirow{2}{*}{$\begin{array}{l}\text { Zon } \\
\text { duur }\end{array}$} & \multirow{2}{*}{$\begin{array}{l}\text { Lucht- } \\
\text { druk }\end{array}$} \\
\hline & gem. & $\min$. & max. & gem. & $\min$. & max. & duur & som & mishim & snel & & & \\
\hline & $\left({ }^{\circ}\right)$ & $\left(^{\circ}\right)$ & $\left({ }^{\circ}\right)$ & $(\%)$ & $(\%)$ & $(\%)$ & (uur) & $(\mathrm{mm})$ & richting & $(\mathrm{m} / \mathrm{s})$ & $(\%)$ & (uur) & (hPa) \\
\hline 3 mei & 10.1 & 2.5 & 14.9 & 69 & 42 & 94 & 1.6 & 1.9 & NW & 3.7 & 40 & 11.8 & 1024.3 \\
\hline 4 mei & 10.6 & 0.6 & 16.5 & 56 & 33 & 97 & 0.0 & 0.0 & 0 & 2.1 & 20 & 12.6 & 1028.7 \\
\hline 9 juni & 16.2 & 10.1 & 21.8 & 67 & 32 & 92 & 0.0 & 0.0 & NW & 2.8 & 30 & 12.5 & 1019.6 \\
\hline 10 juni & 16.9 & 8.5 & 23.0 & 65 & 43 & 95 & 0.0 & 0.0 & $\mathrm{~N}$ & 1.5 & 70 & 8.1 & 1013.9 \\
\hline 29 juni & 16.6 & 13.4 & 22.0 & 75 & 49 & 98 & 1.8 & 6.6 & ZW & 5.0 & 80 & 4.3 & 1011.4 \\
\hline 30 juni & 16.9 & 14.5 & 20.1 & 87 & 77 & 93 & 1.9 & 2.7 & ZW & 4.5 & 70 & 1.5 & 1011.8 \\
\hline 25 juli & 19.7 & 13.8 & 25.0 & 79 & 67 & 97 & 0.0 & 0.0 & W & 2.6 & 60 & 3.3 & 1019.4 \\
\hline 26 juli & 19.2 & 11.6 & 25.1 & 71 & 47 & 98 & 0.0 & 0.0 & W & 1.8 & 70 & 7.4 & 1020.4 \\
\hline 30 aug & 17.1 & 7.7 & 24.3 & 67 & 39 & 98 & 0.0 & 0.0 & NO & 1.4 & 0 & 12.2 & 1024.8 \\
\hline 31 aug & 18.3 & 10.0 & 26.0 & 70 & 41 & 97 & 0.0 & 0.0 & ZW & 1.9 & 10 & 11.7 & 1020.5 \\
\hline $\begin{array}{l}26 \\
\text { sept }\end{array}$ & 12.9 & 7.2 & 18.9 & 84 & 57 & 100 & 0.0 & 0.0 & ZW & 1.6 & 40 & 6.3 & 1023.7 \\
\hline
\end{tabular}




\begin{tabular}{|c|c|c|c|c|c|c|c|c|c|c|c|c|c|}
\hline \begin{tabular}{|l|}
27 \\
sept
\end{tabular} & 13.9 & 4.4 & 21.8 & 71 & 41 & 98 & 0.0 & 0.0 & ZW & 2.3 & 20 & 9.3 & 1025.6 \\
\hline
\end{tabular}

\subsection{Resultaten vangsten steekmuggen}

De Groote Peel wordt gekenmerkt door de aanwezigheid van drie soorten moerassteekmuggen uit de geslachten Aedes en Ochlerotatus, waarbij de soort Aedes cinereus veruit het talrijkst optreedt (Tabel 6, Figuur 6, 7,). De aantallen van deze soort zijn vooral zeer hoog eind juni en eind juli. Dat is uitzonderlijk laat voor deze soort. Mogelijk is dit een gevolg van hevige neerslag in juni waarbijde eitjes die hoger op de taluds in voorgaande jaren zijn afgezet door een tijdelijk peilverhoging nu zijn uitgekomen. Dergelijke eitjes kunnen jaren op het droge liggen en komen pas bij peilstijging, in dit geval na hevige neerslag, uit. Ook de huissteekmug Culex pipiens is talrijk aanwezig, vooral eind juni. Deze hoge aantallen zijn veroorzaakt door de enorme regenval van de drie weken ervoor waardoor er langdurig tijdelijke regenplassen in het gebied (zowel het natuurgebied als het landbouwgebied) aanwezig waren. Omdat de huissteekmug geen verre vlieger is zijn de dieren waarschijnlijk van nabij de vallen aanwezige tijdelijke plassen afkomstig. De vraag is of dit aantal bij een nulmeting zonder voorafgaande heftige regenval ook gevonden zou zijn. Daarnaast is de loodgrijze malariamug (Anopheles plumbeus) regelmatig aangetroffen, wat duidt op de aanwezigheid van lege gierkelders of vergelijkbare situaties.

Tabel 6. Totaal aantal steekmuggen per soort en per vangstmoment.

\begin{tabular}{|l|l|l|l|l|l|l|l|l|}
\hline Datum & $\begin{array}{l}\mathbf{3 - 4} \\
\mathbf{m e i}\end{array}$ & $\begin{array}{l}\mathbf{9 - 1 0} \\
\text { juni }\end{array}$ & $\begin{array}{l}\mathbf{2 9 - 3 0} \\
\text { juni }\end{array}$ & $\begin{array}{l}\mathbf{2 5 - 2 6} \\
\text { juli }\end{array}$ & $\begin{array}{l}\mathbf{3 0 - 3 1} \\
\text { aug }\end{array}$ & $\begin{array}{l}\mathbf{2 6 - 2 7} \\
\text { sept }\end{array}$ & Totaal & \% \\
\hline Aedes cinereus & 0 & 814 & 2135 & 2129 & 94 & 4 & 5176 & 29.6 \\
\hline Ochlerotatus punctor & 45 & 51 & 116 & 17 & 0 & 0 & 229 & 1.3 \\
\hline Ochlerotatus cantans & 3 & 30 & 79 & 6 & 0 & 0 & 118 & 0.7 \\
\hline $\begin{array}{l}\text { Anopheles gr } \\
\text { maculipennis }\end{array}$ & 0 & 1 & 0 & 8 & 1 & 0 & 10 & 0.1 \\
\hline Anopheles plumbeus & 0 & 124 & 39 & 79 & 52 & 26 & 320 & 1.8 \\
\hline Culex pipiens & 2 & 185 & 8702 & 1911 & 517 & 68 & 11385 & 65.2 \\
\hline Culiseta annulata & 0 & 0 & 0 & 4 & 43 & 3 & 50 & 0.3 \\
\hline Culiseta morsitans & 0 & 6 & 0 & 63 & 0 & 64 & 133 & 0.8 \\
\hline Coquillettidia richiardii & 0 & 1 & 0 & 48 & 0 & 0 & 49 & 0.3 \\
\hline Totaal & $\mathbf{5 0}$ & $\mathbf{1 2 1 2}$ & $\mathbf{1 1 0 7 1}$ & $\mathbf{4 2 6 5}$ & $\mathbf{7 0 7}$ & $\mathbf{1 6 5}$ & $\mathbf{1 7 4 7 0}$ & $\mathbf{1 0 0}$ \\
\hline
\end{tabular}




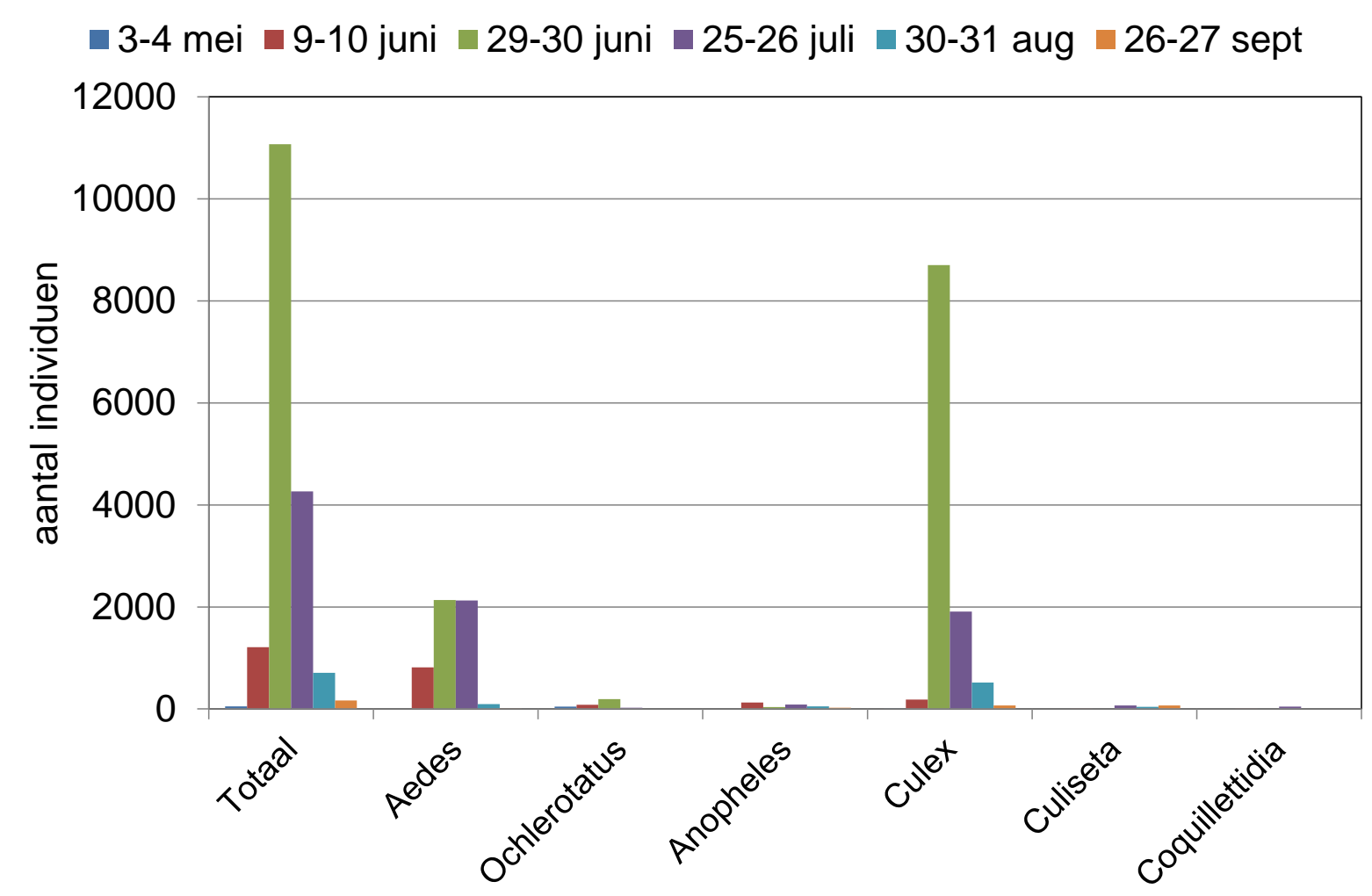

Figuur 6. Totaal aantal steekmuggen. Verdeling van de aantallen over de geslachten per vangstmoment.

$\backsim$ 3-4 mei $₫$ 9-10 juni $\approx 29-30$ juni $\approx 25-26$ juli $\approx 30-31$ aug $\approx 26-27$ sept

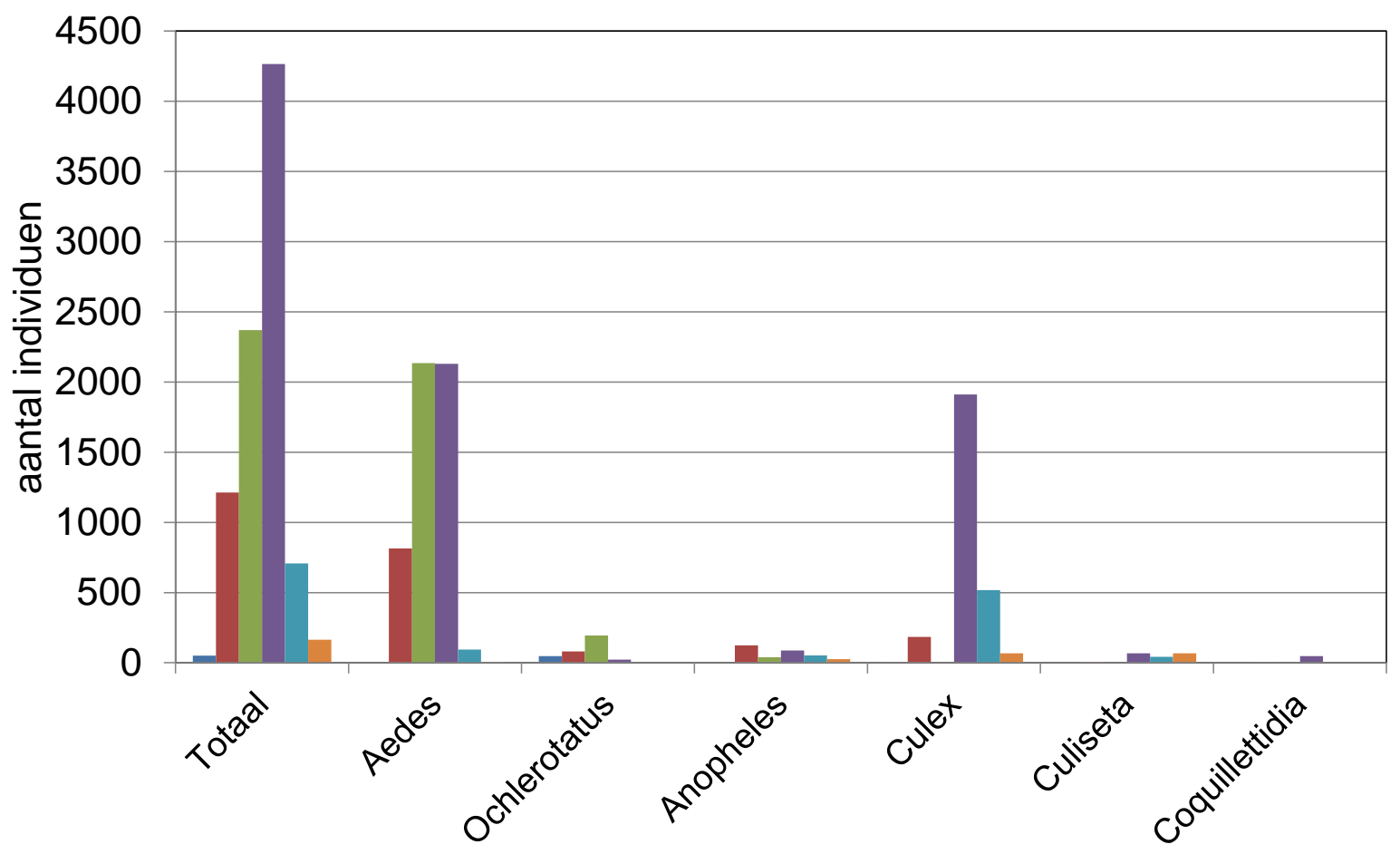

Figuur 7. Totaal aantal steekmuggen zonder Culex piek van eind juni. Verdeling van de aantallen over de geslachten per vangstmoment. 
De vaakst aangetroffen moerassteekmug Aedes cinereus is vooral zeer talrijk op locatie 8 en talrijk op de locaties 9, 12 en 13 (Tabel 7). Op al deze locaties is sprake van redelijke tot hogere mate van overast.

De huissteekmug Culex pipiens is zeer talrijk op de locaties 1, 2.15, 4, 11 en 14 en talrijk op de locaties 7, 9 en 13 (Tabel 7).

Tabel 7. Totaal aantal steekmuggen per soort per locatie

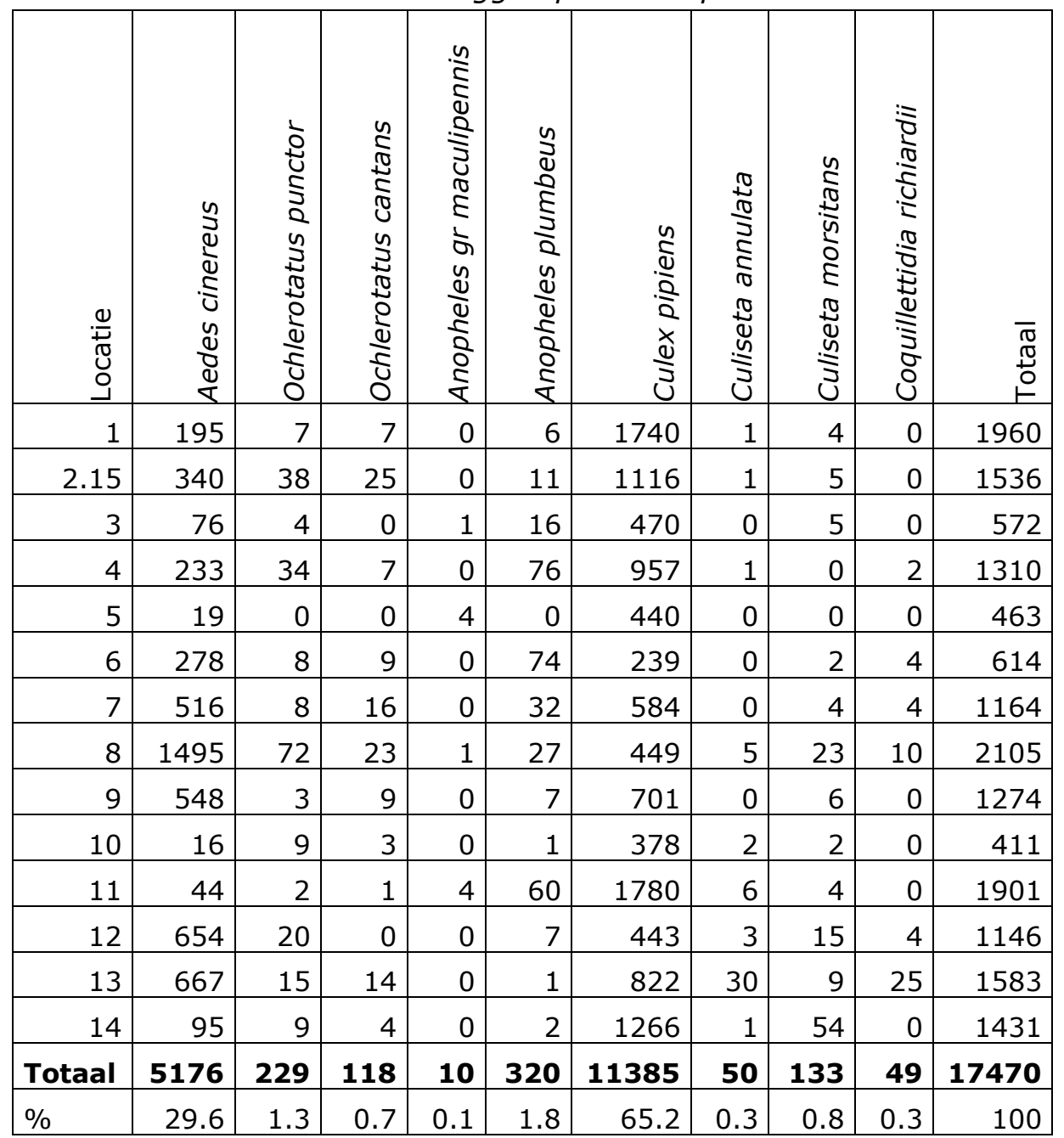

\subsection{Resultaten knutten}

Knutten treden vooral eind juli op (Tabel 8, Figuur 8). De meest talrijke soort was Culicoides gr. festivipennis gevolgd door C. gr. obsoletus.

C. gr. festivipennis is een cosmopoliet die voorkomt in bijna alle natte organische milieus zoals oevers van poelen (bv. Typha, Juncus), drassige organische gronden en permanent geïnundeerde oeverzones. De $C$. gr. obsoletus bewoont vochtige bladbodems, organisch verrijkte bodems vooral nabij stallen en organisch verrijkte bodems op beschaduwde plaatsen en met mest doorwerkte gronden. Het is een dominante soort in met verse en oude mest organisch verrijkte bodem en komt overal voor waar organisch materiaal door de bodem is gemengd, bijvoorbeeld door menging met rottende maisplanten, oude koemest, rottend hooi en dergelijke. De soort lijkt waterverzadigde bodems en overstromingszones te mijden. 
Tabel 8. Totaal aantal knutten en verdeling van de aantallen over de soort(groep)en, uitgesplitst per vangstmoment

\begin{tabular}{|l|l|l|l|l|l|l|l|l|}
\hline Datum & $\begin{array}{l}\mathbf{3 - 4} \\
\text { mei }\end{array}$ & $\begin{array}{l}\mathbf{9 - 1 0} \\
\text { juni }\end{array}$ & $\begin{array}{l}\mathbf{2 9 - 3 0} \\
\text { juni }\end{array}$ & $\begin{array}{l}\mathbf{2 5 - 2 6} \\
\text { juli }\end{array}$ & $\begin{array}{l}\mathbf{3 0 - 3 1} \\
\text { aug }\end{array}$ & $\begin{array}{l}\mathbf{2 6 - 2 7} \\
\text { sept }\end{array}$ & Totaal & \% \\
\hline Culicoides punctatus & 1 & 0 & 19 & 64 & 8 & 6 & 98 & 7.9 \\
\hline $\begin{array}{l}\text { Culicoides gr. } \\
\text { festivipennis }\end{array}$ & 0 & 1 & 0 & 774 & 9 & 13 & 797 & 64.3 \\
\hline $\begin{array}{l}\text { Culicoides gr. } \\
\text { pallidicornis }\end{array}$ & 0 & 0 & 0 & 24 & 0 & 6 & 30 & 2.4 \\
\hline $\begin{array}{l}\text { Culicoides gr. } \\
\text { obsoletus }\end{array}$ & 31 & 0 & 130 & 118 & 2 & 18 & 299 & 24.1 \\
\hline Culicoides pictipennis & 3 & 0 & 0 & 2 & 0 & 0 & 5 & 0.4 \\
\hline $\begin{array}{l}\text { Culicoides gr. } \\
\text { impunctatus }\end{array}$ & 0 & 7 & 3 & 0 & 0 & 0 & 10 & 0.8 \\
\hline & & & & & & & & \\
\hline Totaal & $\mathbf{3 5}$ & $\mathbf{8}$ & $\mathbf{1 5 2}$ & $\mathbf{9 8 2}$ & $\mathbf{1 9}$ & $\mathbf{4 3}$ & $\mathbf{1 2 3 9}$ & $\mathbf{1 0 0 . 0}$ \\
\hline
\end{tabular}

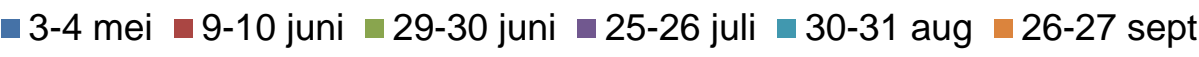

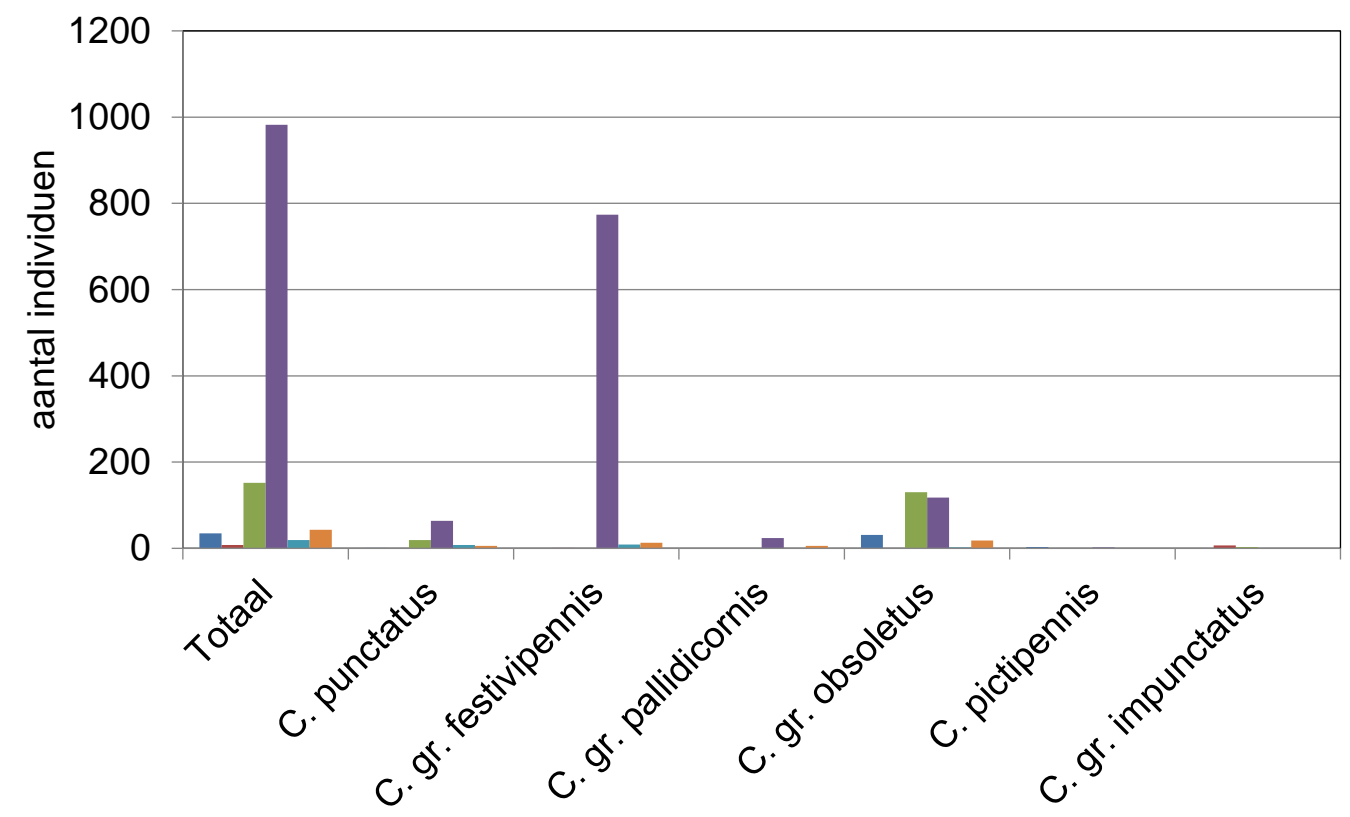

Figuur 8. Totaal aantal knutten en verdeling van de aantallen over de soort(groep)en per vangstmoment.

De vaakst aangetroffen knut Culicoides gr. festivipennis is vooral talrijk op de locaties 10 en 11 (Tabel 9). Alleen Culicoides gr. obsoletus is nog redelijk talrijk op locatie 14 (Tabel 9). 
Tabel 9. Totaal aantal knutten per soort per locatie

\begin{tabular}{|c|c|c|c|c|c|c|c|c|}
\hline 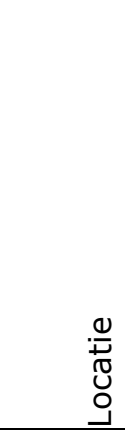 & 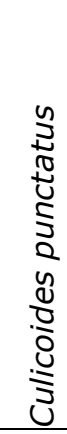 & 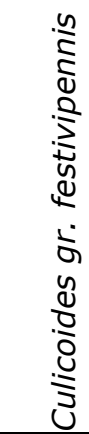 & 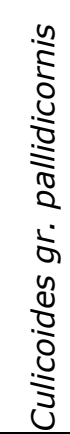 & 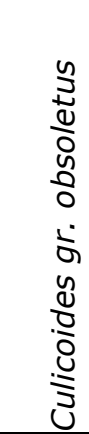 & 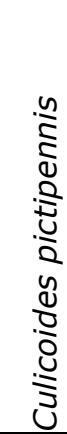 & 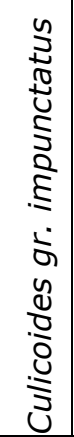 & 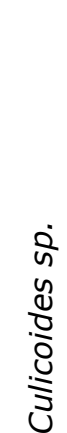 & $\begin{array}{l}\bar{\pi} \\
\mathbb{J} \\
0\end{array}$ \\
\hline 1 & 0 & 0 & 0 & 0 & 2 & 0 & 0 & 2 \\
\hline 2.15 & 1 & 3 & 0 & 18 & 0 & 0 & 3 & 25 \\
\hline 3 & 0 & 0 & 0 & 7 & 0 & 0 & 0 & 7 \\
\hline 4 & 52 & 60 & 0 & 3 & 0 & 3 & 0 & 118 \\
\hline 5 & 0 & 13 & 0 & 9 & 0 & 0 & 0 & 22 \\
\hline 6 & 0 & 88 & 0 & 17 & 0 & 0 & 0 & 105 \\
\hline 7 & 4 & 24 & 1 & 5 & 0 & 0 & 0 & 34 \\
\hline 8 & 2 & 67 & 2 & 12 & 0 & 0 & 4 & 87 \\
\hline 9 & 0 & 1 & 0 & 0 & 0 & 0 & 0 & 1 \\
\hline 10 & 1 & 176 & 1 & 17 & 0 & 0 & 0 & 195 \\
\hline 11 & 6 & 220 & 18 & 15 & 2 & 0 & 0 & 261 \\
\hline 12 & 0 & 84 & 0 & 3 & 0 & 0 & 1 & 88 \\
\hline 13 & 20 & 25 & 0 & 58 & 0 & 7 & 7 & 117 \\
\hline 14 & 12 & 36 & 8 & 135 & 1 & 0 & 3 & 195 \\
\hline Totaal & 98 & 797 & 30 & 299 & 5 & 10 & 18 & 1257 \\
\hline$\%$ & 7.8 & 63.4 & 2.4 & 23.8 & 0.4 & 0.8 & 1.4 & 100 \\
\hline
\end{tabular}




\title{
5. Discussie en conclusies nulmeting stekende insecten
}

\subsection{Steekmuggen}

De in de Groote Peel aangetroffen moerassteekmuggen (geslachten Aedes en Ochlerotatus) behoren alle drie tot soorten die in Nederland in alle hoogveenrestanten frequent optreden.

\begin{abstract}
Ecologie van Aedes cinereus (voor referenties zie Verdonschot et al. 1988)
Het habitat van $A$. cinereus verschilt tussen de larven en de volwassen dieren. Na uitkomen vliegen de volwassen dieren meestal vanuit de broedplaats naar bos. Volwassen dieren van $A$. cinereus komen voor in rivierbossen, bossen, struikgewas, (riet)oevers van grote wateren, graspollen in uitgedroogde poelen, moerassen en venen. In de meer open struik/boom vegetatie en ruigtevegetaties vindt $A$. cinereus zijn optimum en is hier in de zomer steeds abundant aanwezig. Overdag rusten de adulten op deze vochtige beschaduwde en relatief koele plaatsen. In deze habitats worden ze samen met $O$. cantans en $O$. punctor gevonden. In open terrein worden overdag geen vrouwtjes aangetroffen. De volwassen dieren vliegen pas op vanuit hun rustplaats als ze verstoord worden. Ook verplaatsen volwassen dieren zich gedurende de dag van open naar beschaduwde gebieden (rustplaatsen). De grootste activiteit van de vrouwtjes is tijdens de avonduren en de nacht in open terrein. De dieren zijn ook actief in de ochtenduren en overdag. De volwassen dieren zijn hygrofiel en benaderen hun gastheer alleen in de vochtigste delen van de lucht, dus meestal op de benen. Ook overdag is op beschaduwde plekken de aanvlucht sterk, vooral bij hoge luchtvochtigheid, voor en na onweer en bij lichte regen. Op plaatsen waar ze overdag rusten vallen ze op elk moment van de dag aan.
\end{abstract}

Meestal is er sprake van 1 generatie per jaar. De opgaven over het aantal generaties per jaar verschillen echter van een, twee, drie tot meerdere per jaar afhankelijk van gebied. $A$. cinereus zuigt bloed van zoogdieren en vogels. Na het bloed zuigen duurt het vijf tot tien dagen voordat de eieren worden afgezet. Eieren worden afgezet op laag liggende plekken die in regenperioden onder water komen te staan. Elk ei wordt apart afgezet op afgevallen blad en organisch materiaal in bodemdepressies. De eieren worden afgezet in de periode juni-september. Er worden 8 tot 106, gemiddeld 60 eieren per keer afgezet. $A$ cinereus overwintert als ei. Over de aanvang van de eiontwikkeling zijn de meningen nogal verschillend, bij $5-6^{\circ} \mathrm{C}$ tot $12-13^{\circ} \mathrm{C}$. De eieren komen pas in april uit, ook al komen ze eerder onder water. Bij circa $31^{\circ} \mathrm{C}$ sterven de uitgekomen larven of komen de eieren in het geheel niet uit. $A$. cinereus vereist voor een ongestoorde ontwikkeling dus relatief hoge watertemperaturen, die pas bereikt worden als de voorjaarspoelen vaak al uitgedroogd zijn. De helft van de eieren komt uit zonder koude behandeling en heeft geen rustfase. Mocht een tweede generatie optreden dan komen de eieren bij kamertemperatuur circa twee weken na afzetting uit. Eieren zijn vanaf oktober tot half mei aanwezig. De aanwezigheid van volwassen dieren is afhankelijk van het klimatologisch gebied:

- Groot-Brittannië: juni-september, max. juli

- West-Duitsland: half maart-midden juli

- Denemarken: eind mei-oktober

- Oost-Duitsland: vanaf april tot midden augustus, max. half juli

- Polen: mei-midden november

- Finland: voorjaar

De vrouwtjes leven 3-4 maanden en sterven voor de herfst, de mannetjes echter waarschijnlijk al in juni-juli. $50 \%$ van de totale populaties is 13 tot 19 dagen na aanvang van de emergentie uitgevlogen.

De larven van $A$. cinereus kunnen in verschillende watertypen worden aangetroffen. De belangrijkste sturende factor is permanentie van het water, deze soort heeft een voorkeur voor 
temporaire wateren, vooral die wateren die ongeveer de helft van het jaar water bevatten. Door het (meso)thermofiele karakter van $A$. cinereus kunnen geen kortstondige voorjaarspoelen worden bewoond, zoals de echte voorjaarssoorten dat wel doen. Andere belangrijke limiterende milieufactoren zijn chloride (tot een maximum van $261 \mathrm{mg} / \mathrm{l}$ ), dimensie en zuurgraad. $\mathrm{Er}$ is een duidelijke voorkeur van deze soort voor kleine wateren zoals plassen (minder dan $6 \mathrm{~m}^{2}$ en minder dan $40 \mathrm{~cm}$ diep), sloten, greppels, poelen, rivier- en veenmoerassen, oude veenderijen, slenken in venen, broekland, drassige weiden, open verlandingszones van meren en vijvers en overstromingsgebieden van beken en rivieren. Grote permanente wateren en kleipoelen met grijs en alkalien water worden gemeden. $A$. cinereus heeft een duidelijke voorkeur voor zure wateren (licht acidofiel), eventueel met Sphagnum begroeid. De volgende pH-optima zijn gegeven;

- 4.0-6.5

- $3.5-4.4$

- $4.0-6.0$

- $\quad 3.0-3.9$

- $4.1-7.6$

- 4.5-8.2

De optimumtemperatuur voor de larvale ontwikkeling ligt tussen 24 en $25^{\circ} \mathrm{C}$, waarbij de sterfte gering is. Een tweede generatie ontwikkelt zich sneller (hogere temperaturen), maar is minder abundant dan de eerste. Het larvestadium wordt in circa twee maanden tot slechts 8-10 dagen doorlopen, afhankelijk van de temperatuur. Dichtheid van andere soorten is laag in wateren bewoond door $A$. cinereus. Het verschijnen van de larven is afhankelijk van de temperatuur, de volgende waarnemingen zijn bekend:

- Groot-Brittannië: april-juni

- West-Duitsland: begin maart / april-nazomer

- Denemarken: half mei-half juni

- Oost-Duitsland: eind maart / midden-april-september

- Polen: half april-half juli

- Noorwegen: vanaf eind mei

\section{Ecologie van Aedes cantans (voor referenties zie Verdonschot et al. 1988)}

Aedes cantans komt voor in Europa en Azië. Na het uitkomen paren de volwassen vrouwtjes binnen circa een dag. De vrouwtjes steken niet eerder dan twee tot drie weken na de emergentie.

Sommige adulte vrouwtjes hebben aan een bloedmaal niet voldoende om de ovariële ontwikkeling te kunnen voltooien en eieren af te zetten. Als gastheer fungeren zoogdieren. De snelheid van de vertering van het bloed is temperatuur afhankelijk: 14 dagen bij $8{ }^{\circ} \mathrm{C}, 6-12$ dagen bij $30^{\circ} \mathrm{C}$ en 58 uur bij $35^{\circ} \mathrm{C}$. $A$. cantans steekt overdag voornamelijk bij zonsondergang, maar soms ook de gehele nacht, echter alleen in dichte bosbegroeiing of bij hoge luchtvochtigheid. De adulten vliegen vlak boven de grond.

De adulten hebben een voorkeur voor beschaduwde plekken zoals bos en halfopen terrein. De verspreiding wordt beperkt door de begrenzing met cultuurland (barrière). Ook in de perioden van grote activiteit verwijderen de vrouwelijke adulten zich nauwelijks van de bosrand, ze komen wel voor op bosweiden.

De eieren worden 10 tot 13 dagen na het bloedmaal vanaf eind juni tot augustus hoog boven het waterniveau afgezet tussen gevallen loof en mos. Het aantal eieren varieert, afhankelijk van de grootte van de vrouwelijke adult, van 3 tot 121 met een gemiddelde van 48 per legsel terwijl de aantallen in de opeenvolgende legsels afnemen. In de loop van de zomer worden twee tot vier gonotrofe cyclussen voltooid. De tweede generatie ontwikkelt zich sneller (hogere temperaturen) maar is niet zo abundant als de eerste. De eieren gaan vanaf eind september tot begin januari in diapauze en dit wordt geïnduceerd door een temperatuur daling, de terminale factor(en) is (zijn) onbekend. Bij 3 tot $4{ }^{\circ} \mathrm{C}$ begint de ei-ontwikkeling en die strekt zich over een lange periode uit. Slechts een bepaald deel van de eieren komt uit bij elke keer dat ze onder water komen. Eieren, die vroeg in het jaar niet onder water zijn komen te staan, kunnen tot begin september uitkomen, indien ze alsnog onder water komen. Een klein deel van de eieren, die niet onder water kwamen, behoudt de levenskracht voor 3,5 jaar.

A. cantans kan dominerend en plaagvormend zijn. De adulten leven 100 dagen of meer. De volgende opgaven van adulten zijn bekend: 


\begin{tabular}{lll}
$\begin{array}{l}\text { Periode } \\
\text { midden april-midden mei }\end{array}$ & land \\
incidenteel tot in september & DDR & \\
midden mei-midden oktober & & \\
optimum juni-juli & DDR & \\
vanaf midden mei & GBR & \\
april-midden september & & GBR \\
maximum in juli & \multicolumn{2}{c}{ GBRen } \\
vanaf midden mei & Denemarken \\
midden mei-midden september r & DDR \\
april-september & GBR
\end{tabular}

De larven van $A$. cantans zijn oligo- tot mesothermofiel. Ze voeden zich als larve met algen, fungi en detritus. In de loop van de larvale ontwikkeling neemt het aandeel van detritus en fungi in de darm toe tot circa $50 \%$ ten opzichte van algen, als gevolg van toename in de voedingsactiviteit op of nabij de bodem. De hypothese is dat larven in het derde en vierde stadium blad (op de bodem) en plantestengels afschrapen als supplement op het filtreren van algen ( $1 / 3$ van de darminhoud). Beide voedingswijzen zijn nodig voor optimale toename in gewicht. De larven van $A$. cantans hebben een voorkeur voor kleine, temporaire, neutrale, chloride- arme waterverzamelingen in bossen. Hoewel de larve een voorkeur heeft voor bos, is zij niet aangepast aan een bepaald type biotoop. In alle stilstaande wateren in (gemengd en naald) bos worden eieren afgezet, zo ook in hoog- en laagveen (slechts kleine populaties), rietvelden, moerassige terreinen, moerassige randen van meren en vijvers en drassige weiden met geïsoleerd struikgewas. De larve komt alleen voor in niet-organisch verontreinigd water. Het voorkomen van adulten en larven vertoont dezelfde ruimtelijke verdeling.De pH-tolerantie ligt tussen 4,1 en 7,8. De soort is zouttolerant, tot 4000 $\mathrm{mg} / \mathrm{l}$. Er is een voorkeur voor poelen met een diep deel.

$\mathrm{Er}$ is een evenredig verband tussen ontwikkeling van de larven en het temperatuurgemiddelde in stadium 2 tot en met 4 . De larven zoeken actief temperaturen nabij het ontwikkelingsoptimum. De larvale dur is als volgt verdeeld: larvaal stadium 1: 10-16 dagen, 2: 6-15 dagen, 3: 6-15 dagen, 4: 10-25 dagen. De larven zijn in de volgende perioden waargenomen:

Periode

vanaf eind februari

land

midden maart-midden mei,

evt. tot in juli

eind maart-oktober

vanaf midden april

januari-juli en augustus-november

volgroeid begin mei
BRD

DDR

DDR

Denemarken

GBR

DDR

Er zijn aantallen larven gevonden tot 2860 per vierkante decimeter wateroppervlak. Als larvale populaties groot zijn, zijn de adulten kleiner van afmeting en rijpen ook minder eieren als normaal en omgekeerd. Vanaf het uitgekomen ei tot aan de emergentie is de mortaliteit ongeveer 60 tot $95 \%$, vooral bij de eerste stadia. De belangrijkste oorzaken zijn niet bekend, maar predatoren zijn mogelijk onbelangrijk als factor. Het opdrogen van poelen is waarschijnlijk de belangrijkste factor. $\mathrm{Er}$ is een larvaal ontwikkelingsoptimum bij $23^{\circ} \mathrm{C}$. $A$. cantans is univoltien, of bivoltien. De meerderheid van de larven ontwikkelt zich in het voorjaar, de tweede generatie ontstaat alleen bij voldoende regenval in de zomer.

Het popstadium duurt 11 tot 16 dagen. Ondanks niet simultaan uitkomen van de eieren vindt emergentie gelijktijdig plaats.

\section{Ecologie van Aedes punctor (voor referenties zie Verdonschot et al. 1988)}

De verspreiding is holarctisch. $A$. punctor zuigt bloed van zoogdieren en vogels. $A$. punctor vliegt vooral in het vroege voorjaar overdag maar is met name actief in mei en juni. De vrouwelijke adulten vliegen alleen in bedekt terrein, voornamelijk in de namiddag en de avonduren, behalve op winderige en zeer hete dagen. Ze steken ook binnenshuis.

A. punctor heeft een voorkeur voor beschaduwde (relatief) koele plekken. Er is geen verband tussen het voorkomen van adulten en larven. De adult vliegt aanzienlijke afstanden vanaf de 
larvale habitat, ook naar bosgebieden in de omgeving of naar open terrein en is dan even abundant op beschaduwde als op zonnige plekken. De verspreiding wordt niet beperkt door cultuurland.

Omdat de eieren na de ovipositie in diapauze gaan en daarna gelijktijdig uitkomen, na een koude inductie, treden korte perioden van massale ontwikkeling op. Een tweede generatie ontwikkelt zich sneller (hogere temperaturen) dan een eerste generatie, maar is niet zo groot. In herfst en winter komt bij een gunstige weersgesteldheid een klein deel van de eieren uit. De duur tussen het onder water komen en het uitkomen is het meest afhankelijk van de temperatuur. Er is dan ook een evenredig verband tussen de ontwikkeling van de eieren en de gemiddelde temperatuur, mits deze niet boven de optimum ontwikkelingstemperatuur komt Er zijn waarnemingen van eerste larven bij $3,2{ }^{\circ} \mathrm{C}$. Bij veel regenval in het najaar kunnen eieren uitkomen en als larve overwinteren. De verpopping wordt dan vertraagd tot april.

A. punctor treedt vaak massaal op in venen en randgebieden daarvan (dominante acidofiele soort) of licht zuur tot neutraal water.

A. punctor treedt op:

\section{Periode}

vanaf eind april

april-oktober

half mei-juli

midden april-midden oktober, optimum mei en augustus

mei-augustus/september, optimum in juni

mei-eind augustus, optimum maart-midden mei land

$\begin{array}{ll} & \text { DDR } \\ \text { GBR } & \\ \text { Denemarken } \\ \text { Polen } \\ \text { GBR }\end{array}$

DDR

A. punctor is univoltien of bivoltien, er zijn waarnemingen van een overgang van uni- naar plurivoltinisme. Bij voldoende regenval treedt een tweede generatie op. Deze zomergeneratie is belangrijk kleiner dan de voorjaarsgeneratie.

De larve wordt vooral massaal aangetroffen in venig (bruin), licht zuur tot neutraal, moerassig semipermanent water maar is niet aan dit biotoop gebonden. $A$. punctor is acidofiel, met een $\mathrm{pH}$ optimum van 4.

De larven zijn gevonden:

\section{Periode}

november-augustus

begin-half mei

vroege voorjaar-midden augustus

maart-juli, optimum midden mei land

GBR

Denemarken

Polen

DDR

Vergelijkbaar met de Maria- en Deurnesche Peel is de meest talrijke soort Aedes cinereus. De hoge aantallen van deze soort eind juni en eind juli zijn een gevolg van de extreme neerslag waarbij eitjes die hoger op de taluds zijn afgezet door een tijdelijk peilverhoging zijn uitgekomen. $A$. cantans treedt in dezelfde periode op maar is niet plaagvormend mede omdat de verspreiding beperkt blijft tot bos. $A$. punctor treedt vroeger in het jaar op en is bekend een potentiele plaagvormer te zijn.

\footnotetext{
Ecologie van Culex pipiens pipiens (voor referenties zie Verdonschot et al. 1988)

De verspreiding is wereldwijd.

De steekactiviteit is hoog bij schemering en het begin van de nacht tot in de nacht. C. pipiens vliegt huizen in. Deze soort steekt niet tijdens de overwintering.

C. pipiens heeft een voorkeur voor warme zonnige plekken. De actieradius is zeer beperkt, tot circa $30 \mathrm{~m}$, tenzij ze meegevoerd worden door de wind. Zo nam men waar dat een beperkt aantal mannelijke en vrouwelijke adulten in staat bleek een afstand van ongeveer $22 \mathrm{~km}$ te overbruggen. De adulten trekken vanaf midden augustus massaal naar open habitats in het bos.

De vrouwelijke adulten voltooien minstens drie tot vier gonotrofe cyclussen. Vanaf begin april/mei worden de eieren minimaal acht dagen na bloedvoeding als samengekleefde eivlotjes op het wateroppervlak afgezet.
} 
De adulten hebben weinig voorkeur bij de keuze van de ovipositielocaties. Per keer worden tot 150 tot 300 en zelfs 433 eieren afgezet. Ongeveer twee dagen na de ovipositie komen de eieren uit C. pipiens is bij uitzondering plaagvormend, echter nooit in die mate als bij het genus Aedes.

\section{Periode}

april-november

vrijwel het gehele jaar

augustus-half november

april-half oktober land

$\quad$ GBR
Denemarken
Polen
DDR

C. pipiens overwintert als bevrucht vrouwtje, onder andere in \{ kelders, boomgaten, spleten en mergelgrotten ofwel op vochtige plaatsen zonder tocht. Tijdens deze overwintering teren ze in op vetreserves. Overwinterende adulten zijn te vinden vanaf september tot april waarna ze de overwinteringsplaatsen verlaten in maart/april. De winterrust wordt door de lage temperatuur bepaald (niet obligaat). C. pipiens is plurivoltien met drie tot vijf generaties per jaar. Dit aantal wordt bepaald door de temperatuur en de snelheid waarmee een gastheer wordt gevonden. De larven hebben geen speciaal habitat maar worden in allerlei natuurlijke en antropogene, permanente en temporaire wateren aangetroffen zoals watertonnen, waterverzamelingen in donkere ruimten in gebouwen en dakgoten. $\mathrm{Er}$ is een voorkeur voor kleine neutrale, beschaduwde wateren. C. pipiens is ongevoelig voor verontreiniging, lage $\mathrm{pH}$-waarden noch voor een hoog chloridegehalte (tot $4000 \mathrm{mg} / \mathrm{l}$.

Vliegtijden zijn:

Periode

april-november

mei-september

mei-half oktober

juli-half augustus

optimum augustus-september

De pre-imaginale stadia worden in tien dagen (zomer) tot drie maanden (herfst) afhankelijk van de temperatuur en het voedsel en andere externe condities, doorlopen.

De huissteekmug Culex pipiens was om dezelfde reden eind juni talrijk aanwezig. Dit verschijnsel is ook waargenomen op andere monitoringslocaties in Nederland. Het is een gevolg van hogere temperaturen in de maanden daarvoor en extreme natheid in juni. Hierdoor heeft de soort na een aanloop maart-mei in juni tot explosie kunnen komen. Dit verschijnsel is uitzonderlijk.

\section{Ecologie van Anopheles plumbeus}

Anopheles plumbeus kwam voorheen bijna uitsluitend in boomholtes voor. Vooral in met water gevulde gaten in volwassen bomen, in stedelijk en landelijk gebied. Recent komen steeds meer waarnemingen uit septic tanks, rioolstelsels en andere wateren met een hoge belasting met organisch materiaal, zoals waterpartijen met mest of rottende planten.

De soort komt vanaf april/mei tot augustus/september voor. Ze overwinteren als ei of als $4^{\text {de }}$ stadium larve. Het zijn persistente stekers, met een piek in steekactiviteit rond de schemering. Ze steken mens, zoogdieren en vogels.

Daarnaast is de loodgrijze malariamug (Anopheles plumbeus) regelmatig aangetroffen, wat duidt op de aanwezigheid van lege gierkelders of vergelijkbare situaties.

De vraag is of het beeld dat in 2016 is verkregen representatief is voor de Groote Peel. Zeker is dat het zo talrijk optreden van de huissteekmug niet bij de nulsituatie kan worden gerekend. De aantallen van de moerassteekmug A. cinereus zijn mogelijk een gevolg van het weer maar daar is minder zekerheid over. 


\subsection{Knutten}

De meest talrijke soorten knutten waren, vooral eind juni, de soortgroepen Culicoides gr. festivipennis en C. gr. obsoletus. Beide soortgroepen bewonen bijna alle natte organische milieus zoals oevers van poelen (bv. Typha, Juncus), drassige (verrijkte) organische gronden en permanent geïnundeerde oeverzones. Dit habitat past bij landbouwkundig in gebruik zijnde randzones van ontgonnen veengronden waar de vochtige bodems nog wel organisch materiaal bevatte en vaak door bemesting verrijkt zijn.

\subsection{Conclusies}

De metingen van stekende insecten rondom de Groote Peel hadden als doel het vastleggen De eerste vraag luidt: "Is deze nulmeting een betrouwbare vastlegging van de uitgangssitatie van stekende insecten in de Groote Peel?".

De aangetroffen soorten steekmuggen passen bij het beeld van hoogveen restanten in Nederland. De aangetroffen knutten zijn kenmerkend voor organisch rijke natte bodems die vaak in randzones rondom veen restanten te vinden zijn. Het beeld dat in 2016 is verkregen wordt echter mede bepaald door de weersomstandigheden. Dit beeld is niet anders dan een normaal jaar wanneer we naar de soortensamenstelling kijken. Echter het beeld van de aantallen en de maanden waarin hoge aantallen optraden is veel minder betrouwbaar. De moerassteekmug, die typisch is voor hoogveengebieden, $A$. cinereus is in hoge aantallen in juni-juli aangetroffen terwijl normaal de piek in aantallen van deze soort vroeger in het jaar optreedt. Het zo talrijk optreden van de huissteekmug $C$. pipiens past zeker niet bij de nulsituatie en is een gevolg van de extreme neerslag.

Dit betekent dat het antwoord op de eerste vraag is dat de nulmeting geen representatief beeld geeft van de huidige mate van dichtheden van steekmuggen rondom de Groote Peel. De uitkomsten van de metingen zijn minder betrouwbaar door de hevige regens in mei/juni. Een tweede jaar meten zou dit beeld, en vooral van de moerassteekmuggen, kunnen verbeteren.

De tweede vraag luidt: "Zijn er locaties rondom de Groote Peel waar mensen actueel of in potentie overlast kunnen ervaren van muggen of knutten afkomstig uit de Groote Peel?"

De verspreiding van aantallen over de locaties geeft voor vier locaties hohgere aantallen moerassteekmuggen aan. Hier kunnen de bewoners overlast ervaren van moerassteekmuggen uit de Groote Peel. De negen locaties met hoge aantallen huissteekmuggen zijn een gevolg van de extreme weersomstandigheden. De bron van de steekmuggen hoeft niet in de Groote Peel te liggen, kan wel, maar kan ook afkomstig zijn van ondergelopen weilanden e.d.

Op twee locaties kan enige overlast ervaren worden van knutten die mogelijk yuit de Groote Peel afkomstig zijn. 
Dit betekent dat het antwoord op de tweede vraag is dat er momenteel enkele locaties zijn bewoners overlast van moerassteekmuggen of knutten afkomstig uit de Groote Peel zouden kunnen ervaren. Dit met in acht neming van de weerscondities van 2016.

Voor knutten kan dit ook het geval zijn. Daarnaast kunnen knutten ook uit weilanden afkomstig zijn die in pacht bij SBB zijn (bv. locatie 14).

\section{Referenties}

Achtergrond literatuur

Becker, N., Petric, D., Boase, C., Lane, J., Zgomba, M., Dahl, C. \& Kaiser, A. 2003. Mosquitoes and Their Control. Kluwer Academic, New York.

Mohrig W. 1969. Die Culiciden Deutschlands. Parasitol. Schr. 18, 260 p.

Service, M.W. 1993. Mosquitoes (Culicidae). Medical insects and arachnids, 120240.Verdonschot, P.F.M. 2013. Bloedzuigende insecten deel 4. Kriebelmuggen. Dierplagen informatie 4: 6-9.

Verdonschot, P.F.M. 2013. Bloedzuigende insecten deel 3. Dazen. Dierplagen informatie 1: $16-19$.

Verdonschot P.F.M. \& Besse-Lototskaya A., 2012. Leidraad Risicomanagement Overlast Steekmuggen en Knutten: Toelichting op de Leidraad. Alterra-rapport 2298, 59 pp.

Verdonschot, P.F.M. 2012. Bloedzuigende insecten deel 2. Knutten. Dierplagen informatie 4: 16-20.

Verdonschot, P.F.M. 2012. Bloedzuigende insecten deel 1. Steekmuggen. Dierplagen informatie 3: 4-7.

Verdonschot Piet F.M. 2009. Verkenning van de steekmuggen- en knutten-problematiek bij klimaatverandering en vernatting. Alterra rapport 1856. $76 \mathrm{pp}$.

Verdonschot, P.F.M., Schmidt, G., Leeuwen, P.H.J. van \& Schot, J.A. 1988. Steekmuggen (Culicidae) in de Engbertsdijksvenen. RIN, Leersum, rapp. 88/31: 1-109. 


\section{Bijlage 1. Impressie van de meetlocaties.}
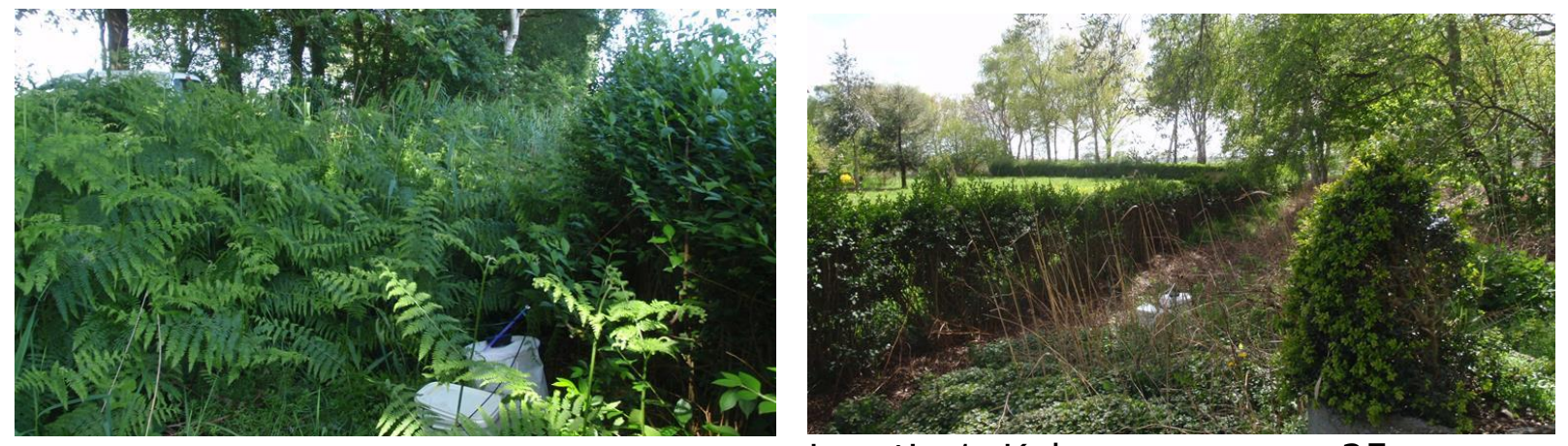

Locatie 1. Kokmeeuwenweg 25.
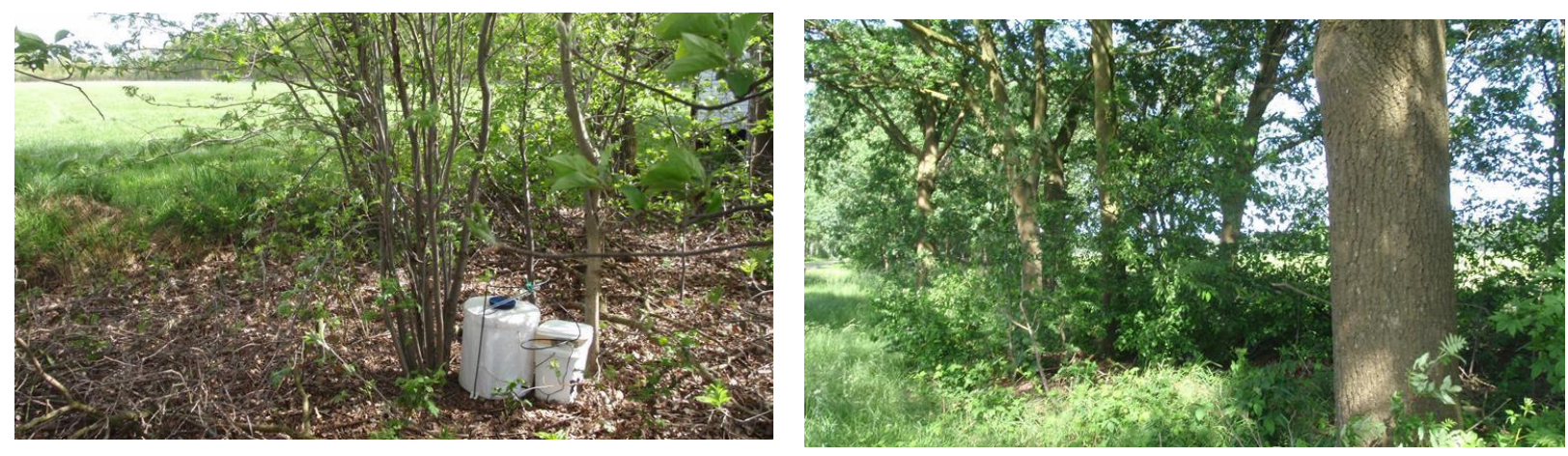

Locatie 2.15. Kokmeeuwenweg 26.

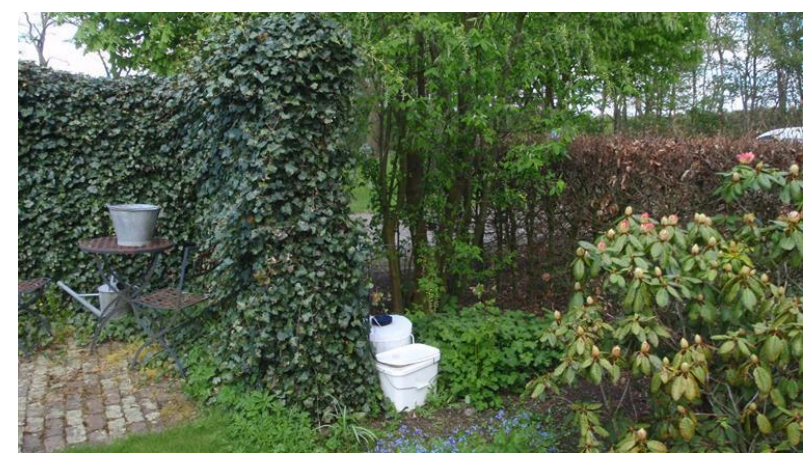

Locatie 3. Kokmeeuwenweg 24.
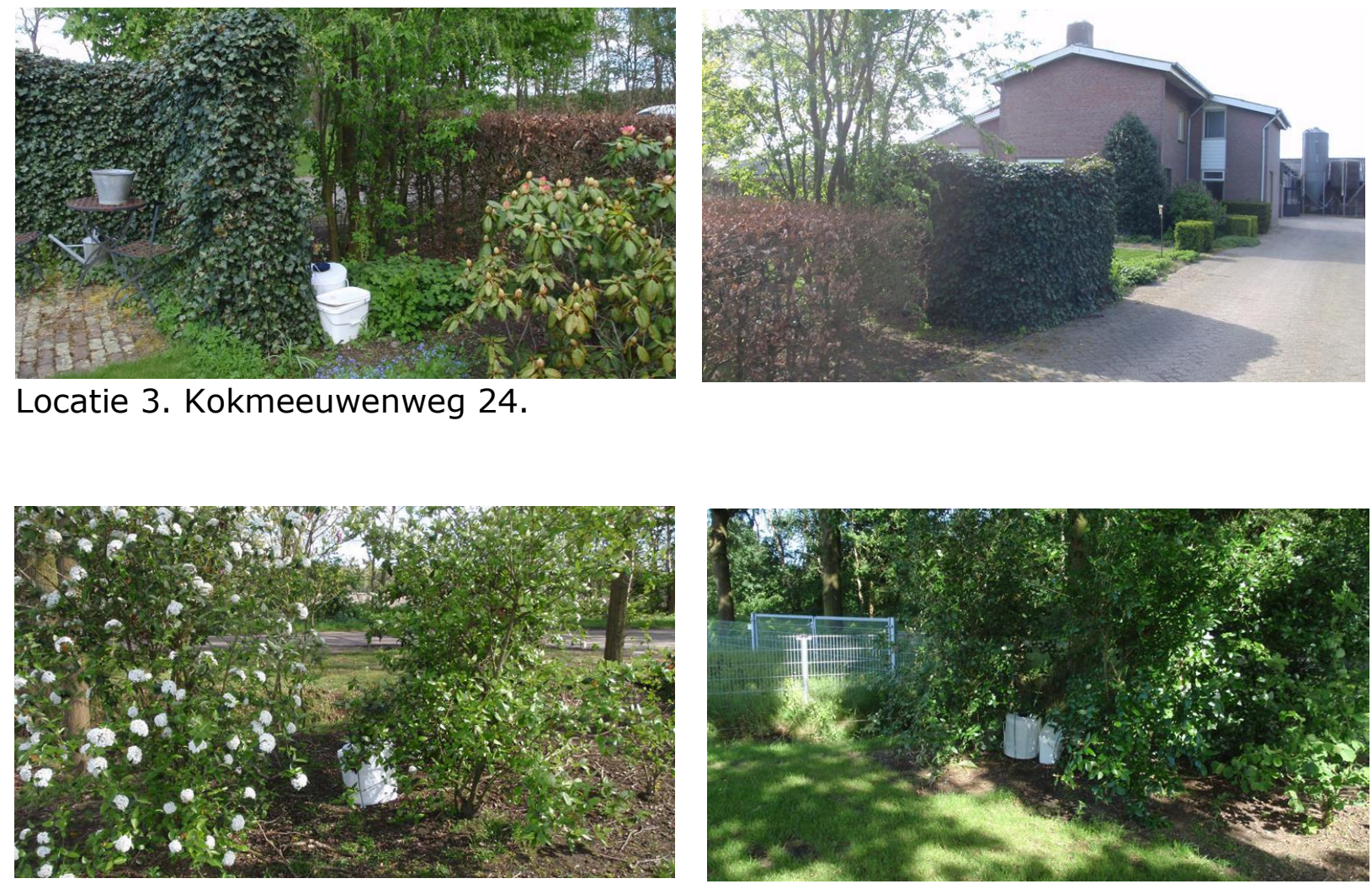

Locatie 4. Kokmeeuwenweg 22. 

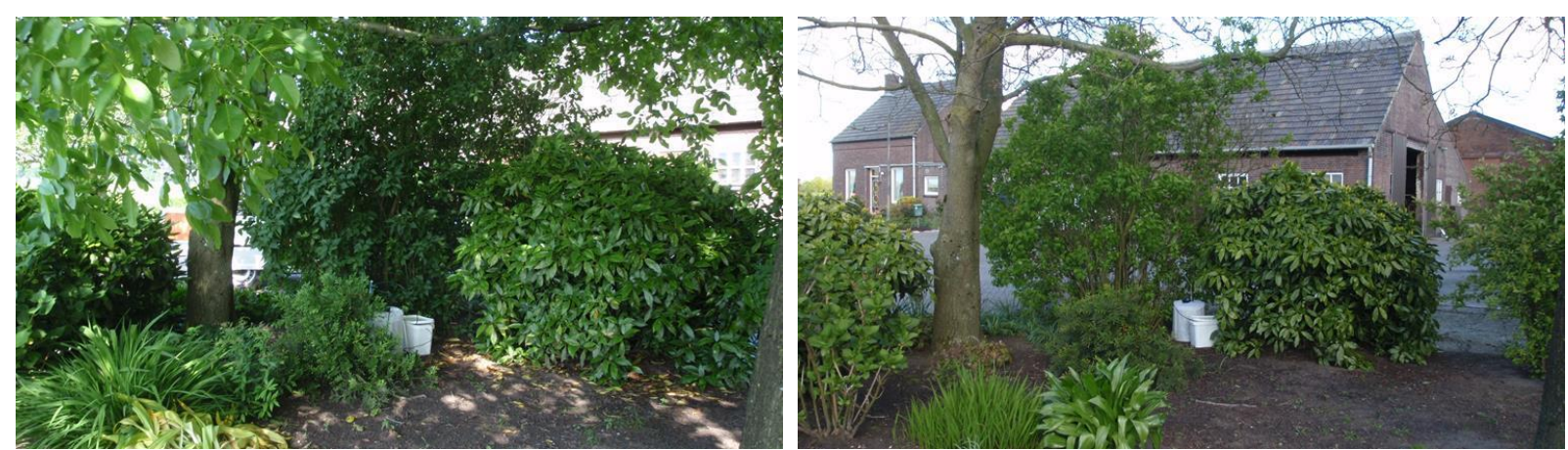

Locatie 5. Kluutweg 7.

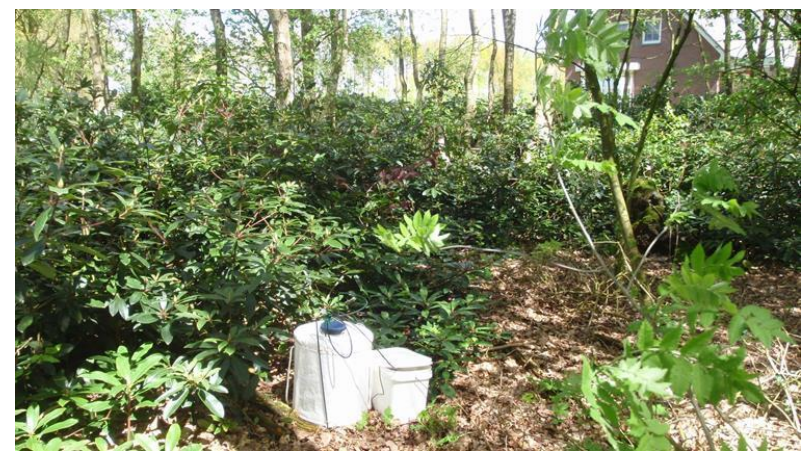

Locatie 6. Tureluurweg 2.
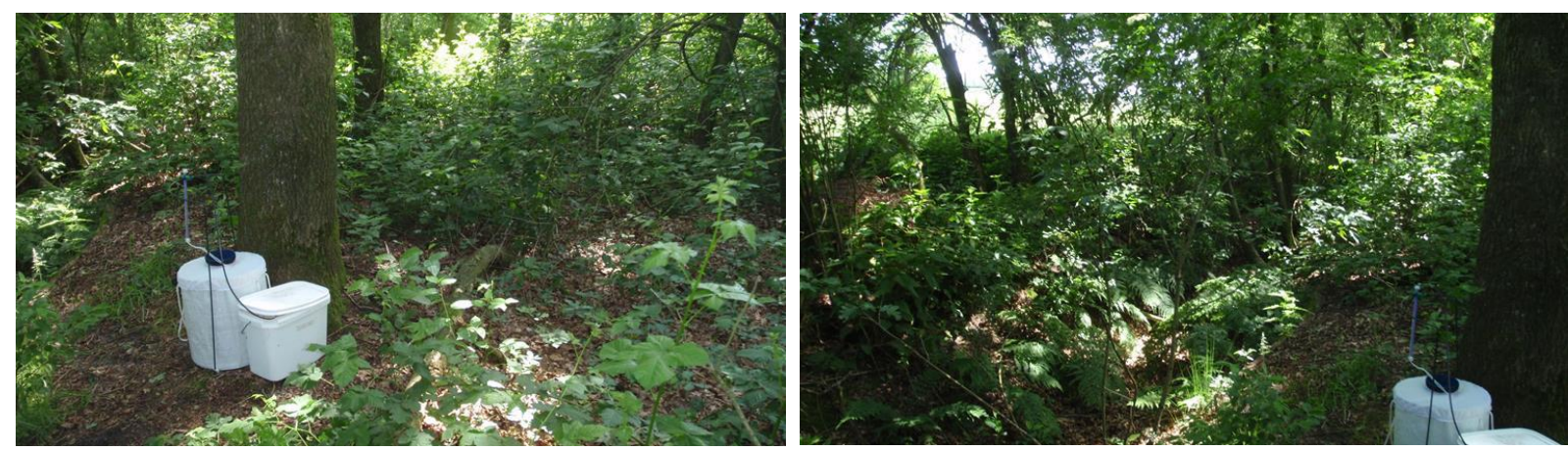

Locatie 7. Bos Tureluurweg.
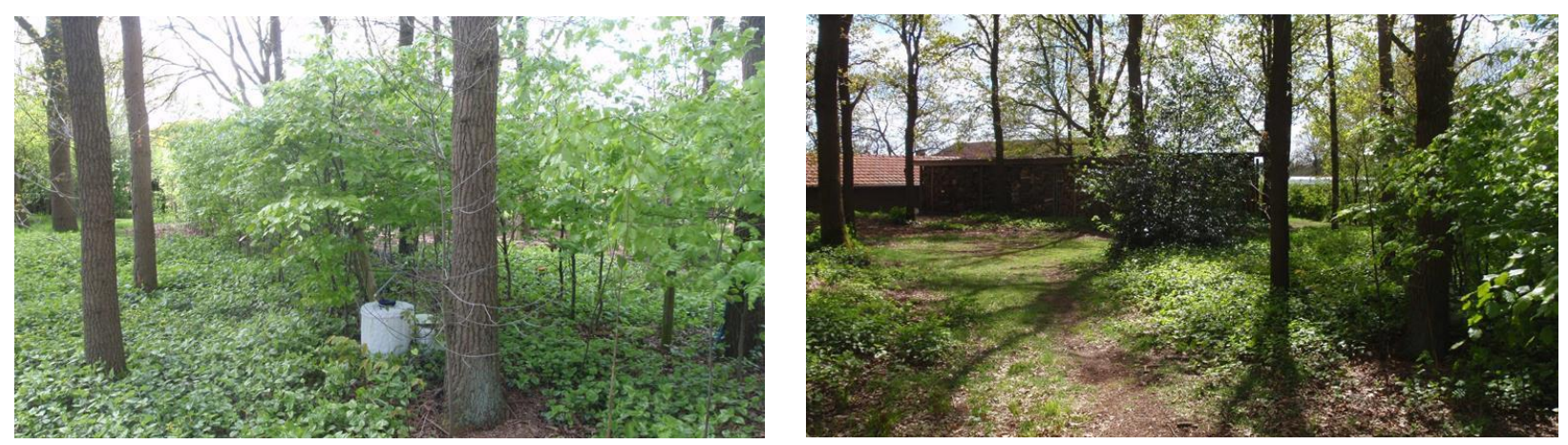

Locatie 8. Oude Dijk 7. 

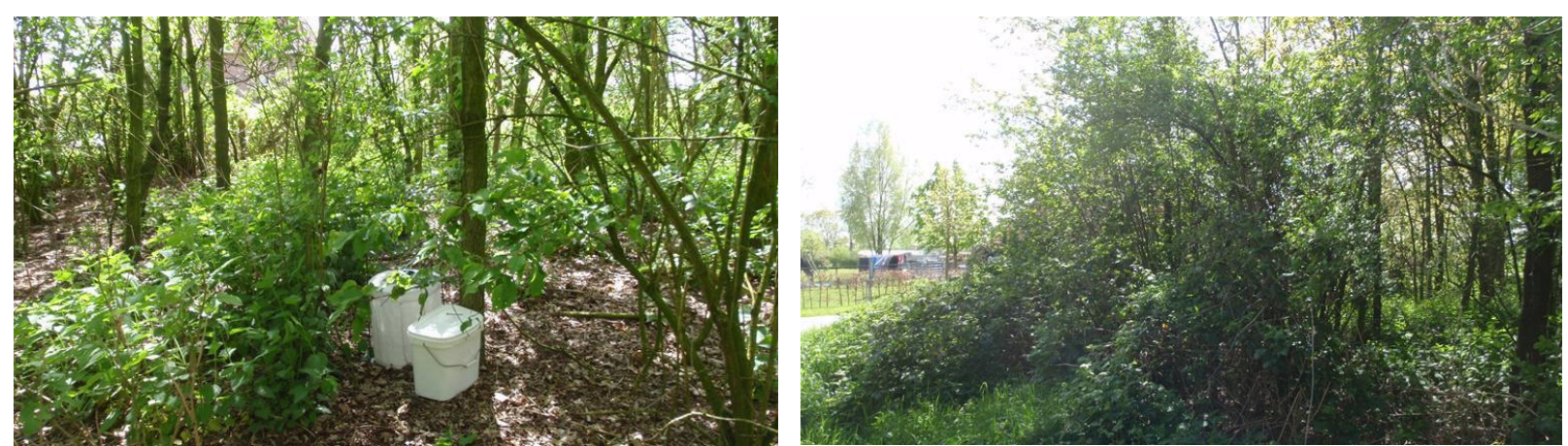

Locatie 9. Moostdijk 19.
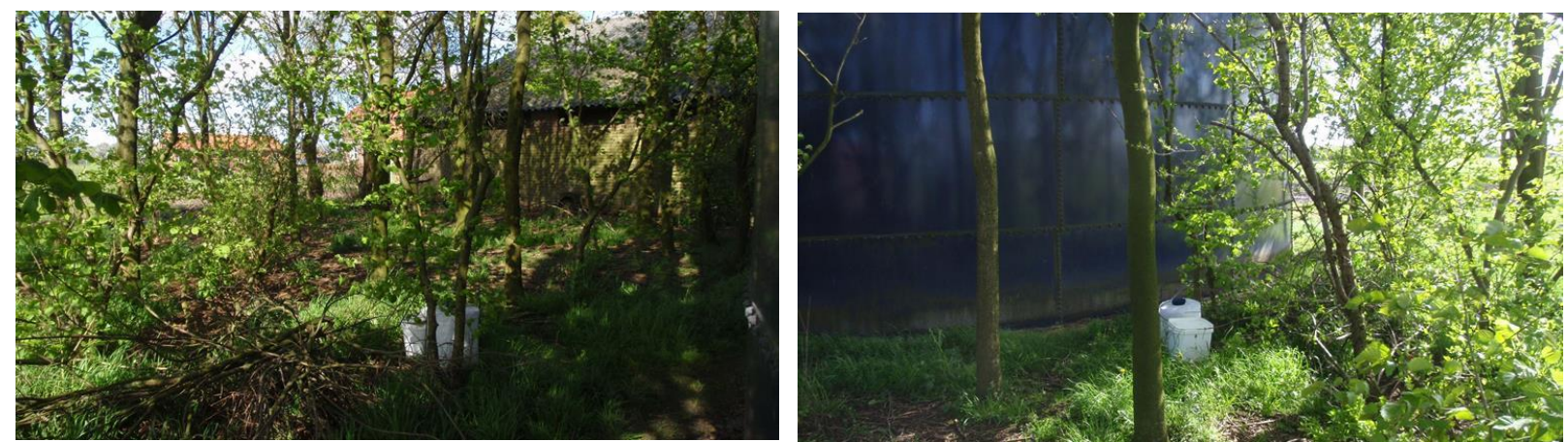

Locatie 10. Vossenbaan 4.
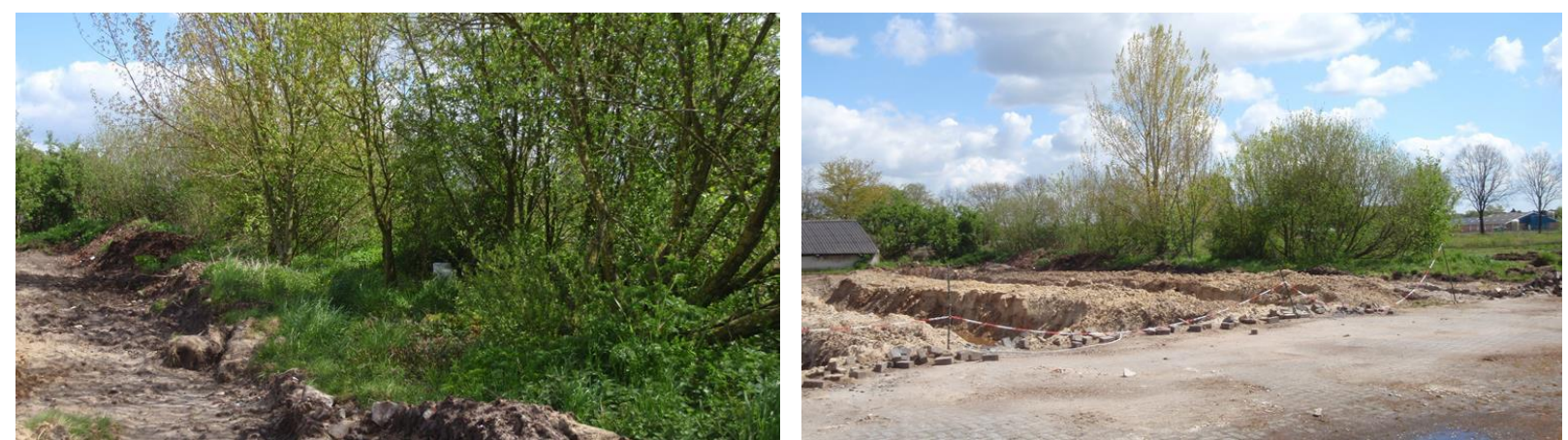

Locatie 11 . Tureluurweg 7.
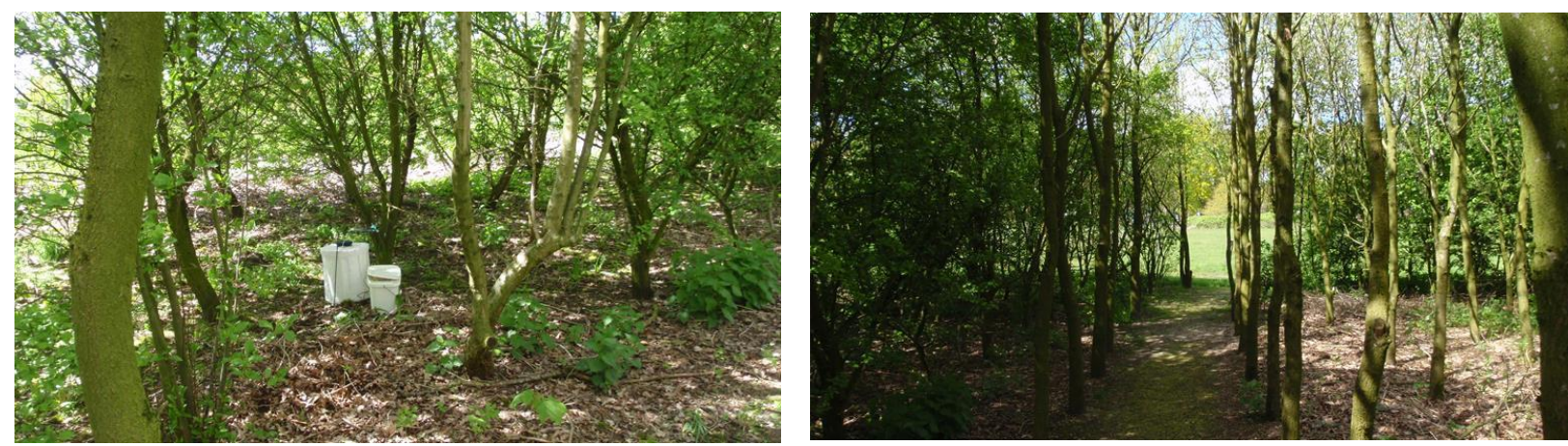

Locatie 12. Oude Dijk 11. 

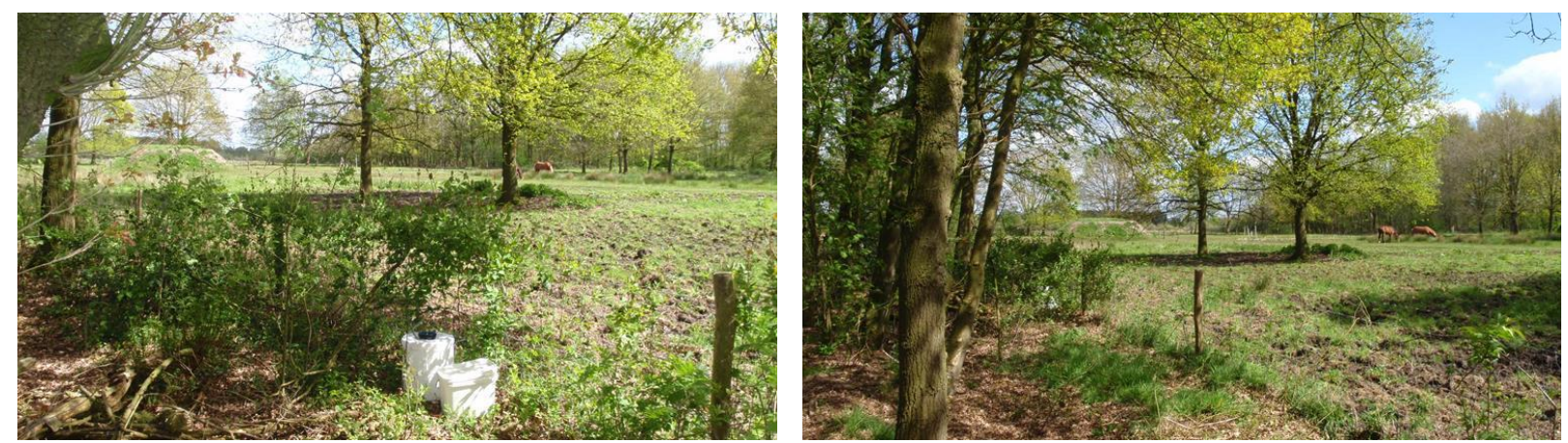

Locatie 13. Meerbaan.
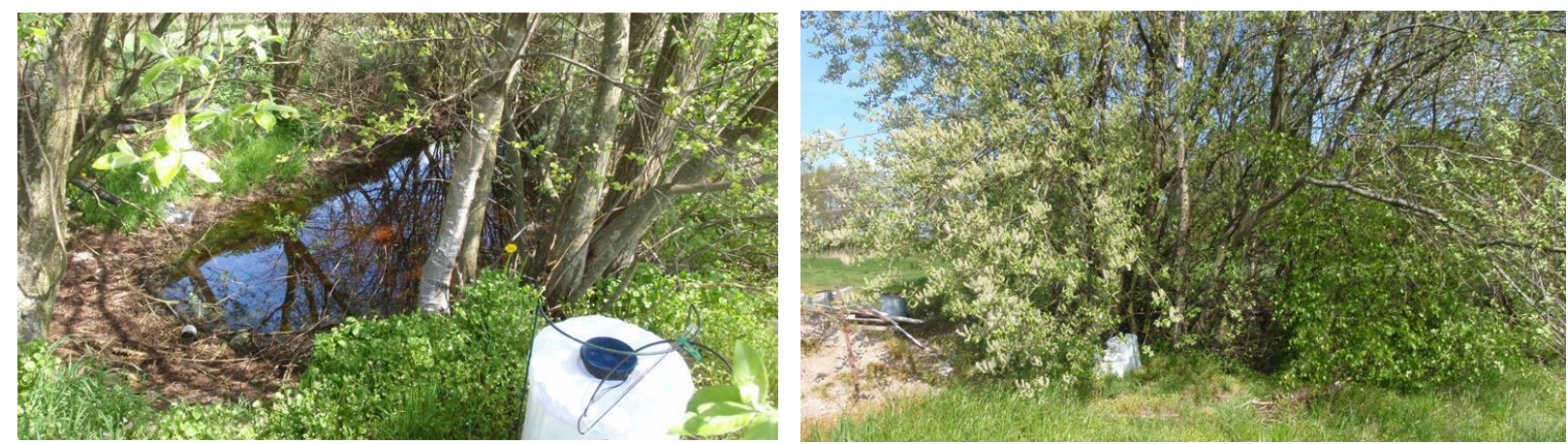

Locatie 14. Berg 6. 
Bijlage 2. Milieukenmerken van de meetlocaties

\begin{tabular}{|c|c|c|c|c|c|c|}
\hline \multirow[b]{2}{*}{ Datum } & \multirow{2}{*}{$\begin{array}{l}\text { Locatie } \\
\text { nummer }\end{array}$} & \multirow{2}{*}{$\begin{array}{l}\text { Beschaduwing } \\
(\%)\end{array}$} & \multicolumn{2}{|c|}{ Temperatuur } & \multicolumn{2}{|c|}{ Luchtvochtigheid } \\
\hline & & & $\begin{array}{l}\min \\
\left({ }^{\circ} \mathrm{C}\right)\end{array}$ & $\begin{array}{l}\max \\
\left({ }^{\circ} \mathrm{C}\right)\end{array}$ & $\begin{array}{l}\min \\
(\%)\end{array}$ & $\begin{array}{l}\max \\
(\%)\end{array}$ \\
\hline \multirow[t]{14}{*}{ 3-4 mei } & 1 & $50-80$ & 1 & 23 & 25 & 99 \\
\hline & 2.15 & $60-80$ & 1 & 17 & 41 & 99 \\
\hline & 3 & $50-60$ & 1 & 18 & 32 & 99 \\
\hline & 4 & $60-80$ & 1 & 17 & 33 & 99 \\
\hline & 5 & $60-80$ & 0 & 17 & 36 & 99 \\
\hline & 6 & $50-80$ & 1 & 16 & 44 & 99 \\
\hline & 7 & $80-100$ & 0 & 17 & 40 & 99 \\
\hline & 8 & $80-100$ & 0 & 18 & 43 & 99 \\
\hline & 9 & $80-100$ & 1 & 17 & 38 & 99 \\
\hline & 10 & $80-100$ & 1 & 18 & 36 & 99 \\
\hline & 11 & $50-80$ & 1 & 19 & 37 & 99 \\
\hline & 12 & $80-100$ & 1 & 16 & 34 & 99 \\
\hline & 13 & $80-100$ & 1 & 19 & 34 & 99 \\
\hline & 14 & $50-80$ & 1 & 19 & 24 & 99 \\
\hline \multirow[t]{14}{*}{ 9-10 juni } & 1 & $60-80$ & 10 & 23 & 41 & 99 \\
\hline & 2.15 & $80-100$ & 13 & 23 & 30 & 99 \\
\hline & 3 & $60-80$ & 10 & 24 & 35 & 99 \\
\hline & 4 & $40-60$ & 10 & 24 & 34 & 99 \\
\hline & 5 & $60-80$ & 10 & 23 & 34 & 99 \\
\hline & 6 & $80-100$ & 9 & 22 & 42 & 99 \\
\hline & 7 & $80-100$ & 9 & 31 & 28 & 99 \\
\hline & 8 & $80-100$ & 10 & 23 & 30 & 99 \\
\hline & 9 & $80-100$ & 10 & 26 & 33 & 99 \\
\hline & 10 & $80-100$ & 10 & 2 & 31 & 99 \\
\hline & 11 & $80-100$ & 10 & 29 & 26 & 99 \\
\hline & 12 & $80-100$ & 9 & 23 & 30 & 99 \\
\hline & 13 & $80-100$ & 11 & 24 & 35 & 99 \\
\hline & 14 & $80-100$ & 10 & 23 & 34 & 99 \\
\hline \multirow[t]{13}{*}{$\begin{array}{l}29-30 \\
\text { juni }\end{array}$} & 1 & $60-80$ & 15 & 20 & 54 & 97 \\
\hline & 2.15 & $80-100$ & 15 & 21 & 52 & 99 \\
\hline & 3 & $80-100$ & 15 & 20 & 61 & 99 \\
\hline & 4 & $60-80$ & 15 & 21 & 46 & 99 \\
\hline & 5 & $80-100$ & 15 & 21 & 45 & 94 \\
\hline & 6 & 100 & 15 & 20 & 47 & 97 \\
\hline & 7 & 100 & 15 & 20 & 55 & 99 \\
\hline & 8 & $80-100$ & 15 & 20 & 50 & 95 \\
\hline & 9 & 100 & 15 & 20 & 58 & 99 \\
\hline & 10 & 100 & 15 & 22 & 46 & 94 \\
\hline & 11 & 100 & 15 & 20 & 53 & 99 \\
\hline & 12 & $80-100$ & 14 & 21 & 43 & 91 \\
\hline & 13 & $80-100$ & 15 & 21 & 47 & 99 \\
\hline
\end{tabular}




\begin{tabular}{|c|c|c|c|c|c|c|}
\hline \multirow[b]{2}{*}{ Datum } & \multirow{2}{*}{$\begin{array}{l}\text { Locatie } \\
\text { nummer }\end{array}$} & \multirow{2}{*}{$\begin{array}{l}\text { Beschaduwing } \\
(\%)\end{array}$} & \multicolumn{2}{|c|}{ Temperatuur } & \multicolumn{2}{|c|}{ Luchtvochtigheid } \\
\hline & & & $\begin{array}{l}\min \\
\left({ }^{\circ} \mathrm{C}\right)\end{array}$ & $\begin{array}{l}\max \\
\left({ }^{\circ} \mathrm{C}\right)\end{array}$ & $\begin{array}{l}\min \\
(\%)\end{array}$ & $\begin{array}{l}\max \\
(\%)\end{array}$ \\
\hline & 14 & $80-100$ & 15 & 22 & 47 & 99 \\
\hline \multirow[t]{14}{*}{$\begin{array}{l}25-26 \\
\text { juli }\end{array}$} & 1 & $40-60$ & 15 & 29 & 50 & 99 \\
\hline & 2.15 & $80-100$ & 16 & 26 & 55 & 98 \\
\hline & 3 & $60-80$ & 16 & 25 & 57 & 98 \\
\hline & 4 & $60-80$ & 16 & 25 & 55 & 99 \\
\hline & 5 & 100 & 15 & 24 & 50 & 99 \\
\hline & 6 & 100 & 15 & 25 & 59 & 99 \\
\hline & 7 & 100 & 15 & 25 & 62 & 99 \\
\hline & 8 & 100 & 16 & 25 & 58 & 99 \\
\hline & 9 & 100 & 16 & 24 & 71 & 99 \\
\hline & 10 & 100 & 16 & 24 & 54 & 99 \\
\hline & 11 & 100 & 15 & 24 & 59 & 99 \\
\hline & 12 & 100 & 15 & 26 & 52 & 99 \\
\hline & 13 & 100 & 16 & 24 & 66 & 99 \\
\hline & 14 & $80-100$ & 15 & 26 & 51 & 99 \\
\hline \multirow[t]{14}{*}{$\begin{array}{l}30-31 \\
\text { aug }\end{array}$} & 1 & $60-80$ & 10 & 29 & 30 & 99 \\
\hline & 2.15 & $80-100$ & 9 & 26 & 36 & 99 \\
\hline & 3 & $60-80$ & 10 & 31 & 30 & 99 \\
\hline & 4 & $60-80$ & 10 & 27 & 41 & 99 \\
\hline & 5 & $80-100$ & 10 & 25 & 38 & 99 \\
\hline & 6 & 100 & 9 & 22 & 45 & 99 \\
\hline & 7 & 100 & 10 & 24 & 38 & 93 \\
\hline & 8 & 100 & 11 & 24 & 38 & 99 \\
\hline & 9 & $80-100$ & 9 & 25 & 42 & 99 \\
\hline & 10 & $80-100$ & 9 & 27 & 36 & 99 \\
\hline & 11 & $80-100$ & 9 & 26 & 39 & 99 \\
\hline & 12 & $80-100$ & 9 & 25 & 35 & 99 \\
\hline & 13 & $80-100$ & 10 & 25 & 40 & 99 \\
\hline & 14 & $80-100$ & 8 & 27 & 33 & 99 \\
\hline \multirow[t]{12}{*}{$\begin{array}{l}26-27 \\
\text { sept }\end{array}$} & 1 & $40-60$ & 6 & 23 & 44 & 99 \\
\hline & 2.15 & $60-80$ & 5 & 25 & 37 & 99 \\
\hline & 3 & $60-80$ & 6 & 23 & 43 & 99 \\
\hline & 4 & $60-80$ & 6 & 20 & 44 & 99 \\
\hline & 5 & $80-100$ & 5 & 20 & 39 & 99 \\
\hline & 6 & $80-100$ & 5 & 18 & 49 & 99 \\
\hline & 7 & $80-100$ & 5 & 18 & 48 & 99 \\
\hline & 8 & $80-100$ & 6 & 20 & 42 & 99 \\
\hline & 9 & $80-100$ & 5 & 20 & 45 & 99 \\
\hline & 10 & $80-100$ & 5 & 20 & 45 & 99 \\
\hline & 11 & $80-100$ & 5 & 21 & 37 & 99 \\
\hline & 12 & $80-100$ & 5 & 20 & 38 & 99 \\
\hline
\end{tabular}




\begin{tabular}{|l|l|l|l|l|l|l|}
\hline \multirow{2}{*}{ Datum } & \multirow{2}{*}{$\begin{array}{l}\text { Locatie } \\
\text { nummer }\end{array}$} & \multicolumn{2}{|l|}{ Beschaduwing } & \multicolumn{2}{|l|}{ Temperatuur } & \multicolumn{2}{l|}{ Luchtvochtigheid } \\
\cline { 3 - 7 } & $(\mathbf{\%})$ & $\begin{array}{l}\min \\
\left({ }^{\circ} \mathbf{C}\right)\end{array}$ & $\begin{array}{l}\max \\
\left({ }^{\circ} \mathbf{C}\right)\end{array}$ & $\begin{array}{l}\min \\
(\%)\end{array}$ & $\begin{array}{l}\max \\
(\%)\end{array}$ \\
\hline & 13 & $80-100$ & 6 & 20 & 39 & 99 \\
\hline & 14 & $80-100$ & 5 & 22 & 36 & 99 \\
\hline
\end{tabular}

